Georgia State University

ScholarWorks @ Georgia State University

$1-3-2008$

\title{
Compensating Differentials in Emerging Labor and Housing Markets: Estimates of Quality of Life in Russian Cities
}

\author{
Mark C. Berger \\ University of Kentucky \\ Glenn C. Blomquist \\ University of Kentucky \\ Klara Sabirianova Peter \\ Georgia State University
}

Follow this and additional works at: https://scholarworks.gsu.edu/uwrg_workingpapers

\section{Recommended Citation}

Berger, Mark C.; Blomquist, Glenn C.; and Peter, Klara Sabirianova, "Compensating Differentials in Emerging Labor and Housing Markets: Estimates of Quality of Life in Russian Cities" (2008). UWRG Working Papers. 5.

https://scholarworks.gsu.edu/uwrg_workingpapers/5

This Article is brought to you for free and open access by the Usery Workplace Research Group at ScholarWorks @ Georgia State University. It has been accepted for inclusion in UWRG Working Papers by an authorized administrator of ScholarWorks @ Georgia State University. For more information, please contact scholarworks@gsu.edu. 
Working Paper 2008-1-3

January 2008

Compensating Differentials in Emerging Labor and Housing Markets: Estimates of Quality of Life in Russian Cities

\author{
Mark C. Berger \\ University of Kentucky
}

Glenn C. Blomquist

University of Kentucky

Klara Sabirianova Peter

Georgia State University

This paper can be downloaded at: http://aysps.gsu.edu/uwrg-research.html

\title{
ANDREW Young SchoOL
}




\title{
Compensating Differentials in Emerging Labor and Housing Markets: Estimates of Quality of Life in Russian Cities
}

\author{
Mark C. Berger ${ }^{\mathrm{a}}$, Glenn C. Blomquist ${ }^{\mathrm{a}^{*}}$, Klara Sabirianova Peter ${ }^{\mathrm{b}}$ \\ ${ }^{a}$ Department of Economics, University of Kentucky, Lexington, KY 40506-0034 USA \\ ${ }^{\mathrm{b}}$ Department of Economics, Andrew Young School of Policy Studies, Georgia State University, \\ Atlanta, GA 30302-3992 USA
}

January 19, 2007 version

$\diamond$ Earlier presentations of this research were given at a session to honor the memory of Sherwin Rosen at the Association of Environmental and Resource Economists / Allied Social Sciences Association meetings in Washington, DC on January 3-5, 2003, the New Economic School Conference in Moscow, Russia on December 19-21, 2002, the William Davidson Institute / Centre for Economic Policy Research Annual International Conference on Transition Economics in Portoroz, Slovenia on June 23-26, 2001, the Annual Conference of the American Real Estate, Urban Economics Association / Allied Social Sciences Association in New Orleans, LA on January 7, 2001, and workshops at University of Illinois in Urbana-Champaign, University of Kentucky, University of Washington, Swedish University of Agricultural Sciences in Umeå, Stockholm School of Economics, and Linköpings University, Sweden. We gratefully acknowledge the contribution of the late Michael Swafford, who generously supplied encouragement and portions of the data. We acknowledge the NSF (Research Grant SES 0111783) for funding of data collection. We appreciate helpful comments from Brent Ambrose, Tim Bartik, John Earle, Yuriy Gorodnichenko, Bengt Kriström, Dan McMillin, Stuart Rosenthal, Steven Spillman, Ken Troske, Editor Jan Brueckner, two anonymous referees, and participants in the various sessions and workshops. We thank Brandon Fleming, Dmitry Krutikov and Viktor Orekhov for excellent research assistance. Responsibility for the views expressed in this paper rests solely with the authors. Mark Berger passed away April 30, 2003. He is missed.

JEL Classification: D5, H4, J3, J6, P2, P3, Q2, R1, R2

Key words: compensating differentials, amenities, hedonic implicit prices, quality of life, transition economy

*Corresponding author. E-mail address: gcblom@uky.edu 


\begin{abstract}
The purpose of this paper is to see if an equilibrium model of compensating differences for amenities can be applied to a major transition economy, Russia. We analyze Russian labor and housing markets using data from the Russian Longitudinal Monitoring Survey (RLMS) augmented by city and regional-specific characteristics from other sources. Our estimated wage and housing value equations suggest that workers are compensated for differences in climate, environmental conditions, ethnic conflicts, crime rates, and health conditions, after controlling for worker characteristics, occupation, industry, and economic conditions, and various housing characteristics. We find evidence that these compensating differentials exist even after controlling for the regional pay differences ("regional coefficients") used by the Russian government to compensate public sector workers for living in regions that are designated as less desirable. Quality of life, as measured by a group of eleven amenities, varies substantially. The highest ranked cities tend to be in relatively warm areas and areas in the western, European part of the country. Our quality of life index is positively correlated with net migration into a region, suggesting workers are attracted to amenity-rich locations. Overall, we find that a model of compensating differentials with controls for disequilibrium yields useful information about compensation for location-specific amenities and quality of life in this large transition economy.
\end{abstract}




\section{Introduction}

Market economies tend to generate compensating differentials in housing and labor markets for location specific amenities. These local amenities include climate, which is natural, urban conditions, which are produced, and environmental quality, which is partly natural and partly produced. In markets that are functioning smoothly, compensating differentials are a basic tool for understanding the consequences of movements of people and businesses across regions and cities. Compensating differentials are also used to estimate the values people place on goods that are not typically sold in markets and to measure quality of life across geographic locations. In Western economies such as in the United States, there have been several studies that estimate compensating differentials in labor and housing markets and which rank areas by quality of life and many more related studies. The review of this literature by Gyourko, Kahn, and Tracy [23] offers a critical synthesis of more than 70 books, articles, and papers.

A related and potentially important use of the estimates of the values of amenities is as shadow prices for amenities that are not typically included in national income accounts.

Construction of an index that is more comprehensive than Net National Product, such as Nordhaus and Tobin' [36] Measure of Economic Welfare, requires monetary values of the nonmarket goods and services. Green accounting requires monetary values of measures of environmental and natural resource services. ${ }^{1}$ Considerable interest in green accounting exists in the U.S. and, in fact, around the world; see Nordhaus [35] and Heal and Kriström [26]. If compensating differentials can be estimated for emerging markets, the prospect for successful implementation of green accounting is more promising for more of the world. In order to use a compensating differentials approach, equilibrium must exist whether or not the economy is in transition.

\footnotetext{
${ }^{1}$ As discussed in Heal and Kriström [26] other approaches such as defensive expenditures and politically determined willingness to pay are candidates for estimating the monetary values of amenities. Stated preference approaches can be used to estimate the value of amenities. Hoehn and Randall [27] provide a state of the art example and Carson [10]
} 
Compensating differentials represent an equilibrium adjustment mechanism in housing and labor markets that matches consumers/workers and firms with different preferences and production technologies. Even in a mature, market economy such as in the U. S. one might be skeptical of the usefulness of this equilibrium model. A major study by Greenwood, Hunt, Rickman, and Treyz [22] tests for spatial equilibrium. They estimate an equilibrium relative income at which no net migration would occur. By comparing the actual income to the estimated equilibrium income for each area, they find little evidence of disequilibrium for the period 19711988 in the U.S. They find that classification of areas that are amenity-rich and amenity-poor and comparing them with estimates from quality of life index values from the Blomquist, Berger, and Hoehn [6] study yields only minor classification differences. Gyourko, Kahn, and Tracy [23] provide a reminder of the crucial nature of this underlying equilibrium assumption of the compensating differentials framework.

Surely any concern about equilibrium is magnified if a compensating differentials framework is applied to an economy making a transition from central government planning to a decentralized market system. The basic question is whether or not compensating differentials are generated in a transition economy, and if they are what this implies about geographic variation in quality of life. ${ }^{2}$ Are the market forces strong enough to produce observable wage and housing price differences across regions that are related to differences in location specific amenities? The purpose of this paper is to see if an equilibrium model of compensating differences for amenities can be applied to a major transition economy, Russia. The goal is to estimate wage and housing hedonic equations, amenity values, and a quality of life index to see if reasonable results emerge.

provides an overview of contingent valuation. An alternative approach would be to make inferences from extended surveys of happiness that have been applied to macroeconomic conditions, see di Tella, MacCulloch and Oswald [13]. ${ }^{2}$ Total utility for individuals is comprehensive and depends on at least the consumption of marketed goods and services, goods produced within the household, as well as the bundle amenities that is available in the areas where the individuals live and work. Quality of life, as defined in this paper in equation 5 below, is the value to households of a bundle of amenities in an area, not a measure of total utility. 
To our knowledge no one has attempted a systematic analysis of compensating differentials for location specific amenities for a transition economy.

Few would question the challenge given the change in Russia induced by the transition that began more than a decade ago. Fischer and Sahay [15] describe Russia's promising start with privatization and stabilization in the early and mid 1990s. However, this period was followed by fiscal problems that resulted in financial collapse in 1998 and the lowest level of output since the transition began. The ratio of real Gross Domestic Product in 1999 to that in 1989 was only 0.59; see Fischer and Sahay [15, p.3]. Adjustments in the labor and housing markets are not likely to be smooth and quick.

Among transition economies, Russia offers a unique opportunity to examine compensation for location-specific amenities. The Russian Federation and its 89 oblasts, republics, and krays, or regions, stretch across 11 time zones. Important for our analysis is the fact that there is wide variation in the distribution of amenities across regions. For example, for cities the number of registered crimes per 1,000 population has a mean of 23.9 with a standard deviation of 15.4 and a range from 1.7 to 210.9 . This kind of variation allows us to examine any wage and housing price differences, holding constant nonamenity factors affecting wages and housing prices. Existence of compensating differentials allows valuation of quality of life in Russian cities as well as estimation the amount of influence of central government planners through "regional coefficients" they used to adjust wages.

\section{An Equilibrium Model of Wages, Rents, and Amenities}

The fundamental framework for analyzing compensating differentials and quality of life was developed by Rosen [39] and Roback [38]. In this framework consumers/workers with similar preferences and firms with similar production technologies face different location specific amenity bundles across geographic areas. In spatial equilibrium, so that there is no incentive to 
move, differences in wages and/or housing prices develop to require payments for locating in amenity rich areas and provide compensation for locating in amenity poor areas. Applications with heterogeneous individuals have led to including nonlocation characteristics of workers and houses as control variables. The full implicit price of a specified amenity is the sum of the housing price differential and the negative of the wage differential. In Blomquist, Berger, and Hoehn [6], we expand this framework to incorporate agglomeration effects and use this form of the implicit price of amenities. We find capitalization of the value of local amenities into local labor markets and housing markets.

In this paper we analyze cities. As in Blomquist, Berger, and Hoehn [6], households derive utility from consumption of a composite good, local housing, and local amenities. A household gets access to the amenities of the $k^{\text {th }}$ city through purchase of housing $h_{k}$ in that city, where $k=1 \ldots n$ and $n$ is the number of cities. Both the composite good and housing are purchased out of labor earnings. Households are endowed with one unit of labor each that they sell to local firms and earn a wage $w_{k}$. All income is labor income and labor is homogeneous. In city $k$, household well-being is

$$
v^{k}=v^{k}\left(w_{k} ; p_{k} ; a_{k}\right)
$$

where $v^{k}($.$) is the indirect utility function, p_{k}$ is the price of housing in city $k$, and $a_{k}$ is an index of local amenities. The price of the composite good is fixed and suppressed. Wages increase utility, $\partial v^{k} / \partial w_{k}>0$, and the price of housing decreases utility, $\partial v^{k} / \partial p_{k}<0$. An increase in the amenity index will increase utility if $a$ is an amenity for consumer/workers, $\partial v^{k} / \partial a_{k}>0$, decrease utility if $a$ is a disamenity for consumer/workers, $\partial v^{k} / \partial a_{k}<0$, and have no effect on utility if $a$ is not an amenity factor.

Firms produce the composite good by combining capital and local labor and production technology is constant returns to scale. Let the prices of the composite good and capital be fixed 
by international markets, and further let the wages and prices be normalized on the price of the composite good. Set the price of the composite good equal to one. In city $k$, unit production costs

are

$$
c^{k}=c^{k}\left(w_{k} ; a_{k, N}, N\right.
$$

where $c^{k}$ is the unit cost function for a firm and the price of capital is left implicit. $\mathrm{N}$ is city population and is determined by the fixed amount of land in the city divided by residential demand for land. By Sheppard's lemma a firm's demand for labor is $\partial c^{k} / \partial w_{k}>0$. If $a$ is a production amenity, then costs are lower, $\partial c^{k} / \partial a_{k}<0$. If $a$ is a production disamenity, then costs are higher, $\partial c^{k} / \partial a_{k}>0$. Costs are unaffected if $a$ is not a production amenity factor. ${ }^{3}$ Because we do not observe urban sub-areas, we do not consider variation of amenities within a city or agglomeration which affects all jurisdictions within an urban area. Our model does not include land prices because the land market did not develop in Russia until $2000 .^{4}$

Equilibrium results from sufficient movement of households and firms among cities so that wages and housing prices clear the labor and housing markets. Spatial equilibrium implies that households in all cities experience a common level of utility, $u^{0}$, and unit production costs are equal to the unit production price. For any city, the set of wages and housing prices that sustains an equilibrium satisfies the system of equations

$$
\begin{aligned}
& u^{0}=v^{k}\left(w_{k} ; p_{k} ; a_{k}\right) ; \\
& 1=c^{k}\left(w_{k} ; a_{k}, N\right)
\end{aligned}
$$

\footnotetext{
${ }^{3}$ An amenity factor can affect both households and firms, and production amenities can be important. Beeson and Eberts [4] found that approximately 60 percent of the wage differential that compensates for amenity differences in the U.S. was due to productivity (firm amenity) differences.

${ }^{4}$ There was practically no market and pricing of the land that a firm could buy until 2000. By the end of 2000, less than 1 percent of all land in Russian settlements was property of legal entities (enterprises). By July 2002, the share of privatized urban land was negligible. St. Petersburg city had the largest share of privatized urban land among all cities; it was only 1.4 percent. The share in other cities for which data was reported ranged from 0 to 0.2 percent. Until 2002 land privatization was prohibited in Moscow. See Khakhalin [29].
} 
and the condition that requires the population of the nation to equal the sum of the city populations. Equilibrium differentials for wages and housing prices can be used to compute implicit prices of the amenities, $f_{k}$. By taking the total differential of equation $3 a$ and rearranging, the implicit price of an amenity can be found, $f_{k}=\left(\partial v^{k} / \partial a_{k}\right) /\left(\partial v^{k} / \partial w_{k}\right)$. For amenity $a_{k}$ the full implicit price is

$$
f_{k}=h_{k}\left(\mathrm{~d} p_{k} / \mathrm{d} a_{k}\right)-\mathrm{d} w_{k} / \mathrm{d} a_{k}
$$

where $h_{k}$ is the quantity of housing purchased by a household in city $k,\left(\mathrm{~d} p_{k} / \mathrm{d} a_{k}\right)$ is the equilibrium housing price differential and $\left(\mathrm{d} w_{k} / \mathrm{d} a_{k}\right)$ is the equilibrium wage differential. The full implicit price is combination of the effect in the housing market and the effect in the labor market. Comparative static analysis of such a model shows that the signs of the housing price and wage differentials depend on the effect of the amenity factor on households and the effect of the amenity factor on firms. A pure consumption amenity, that does not have an effect on firms, is expected to have a full implicit price that is positive. It is the weighted sum of the differentials in the housing market and labor market that is expected to be positive. It is not necessary that both the housing prices are higher and the wages are lower in cities that are rich in the consumption amenity. As a practical matter, the amenities factors which we use might affect consumers/workers and firms. For example, the area crime rate can be a disamenity to both residents and firms in the city. The quality of life index (QOLI) for any city $k$ is

$$
\mathrm{QOLI}_{k}=\Sigma_{i} f_{i} a_{k i} \quad k=1, \ldots, N
$$

QOLI is the sum of the endowments of the $i$ amenities in city $k$ of $\mathrm{N}$ cities where each amenity is weighted by its estimated full implicit price based on the wage and housing price differentials. As 
such, the QOLI is an estimate of the total compensation or payments for the amenities in city $k$ made through the housing and labor markets. 5,6

\section{Compensating Differentials under Plan and Market}

Although the equilibrium assumptions of the model may make one wonder about how appropriate this framework is for a transition economy, the concept of compensating differentials is not a foreign concept in Russia. Compensating differentials existed under socialism even though wages and housing prices were not determined by market forces. In any society, people care about income and housing and have preferences for cities that are rich in amenities. Government planners have faced these individual preferences and have responded by offering inducements for working in less desirable areas. Soviet policy included the "efficient and socially necessary" allocation of labor across regions. The goal of that policy was attracting workers to locations with unfavorable climate and environment. Soviet channels of worker reallocation involved planned distribution of graduates, organized recruitments to the "bad" regions, housing subsidies, paid moving expenses and other government actions. One of the most important tools of the worker relocation policy was regional wage coefficients (multiples of the base salary) that provided different levels of compensation for workers depending on the location of their job.

\footnotetext{
${ }^{5}$ For small variations in the typical amenity bundle the difference in the QOLI index approximates the value households place on the amenities. Tim Bartik has suggested an alternative to the Rosen, linearized approach that is used in this paper. The alternative would measure the combined wage and housing price differential associated with the change in amenities city to city using the wage and housing hedonic functions. Values from such a nonlinear index would be more closely related to willingness to pay suitable for benefit cost analysis. He also suggests that this alternative may not yield greatly different values for amenity bundles given the semilog specification we use in estimation of the wage and housing equations.

${ }^{6}$ This compensation or payment may not equal willingness to pay for the typical household if there is heterogeneity across households in tastes for amenities. This can happen if households self select into cities based on unobservable preference characteristics. Households that fear crime less or can better protect themselves against crime will sort into higher crime cities and will have a relatively low value of lower crime rates. Chay and Greenstone [11] and Bajari and Kahn [2] demonstrate that this sorting can bias estimates of willingness to pay. This effect may not be as great in Russia because sorting is not as complete as in the U.S.
} 
The Soviet housing system was also highly distorted by administrative regulations and suffered from chronic shortages, long waiting lists, subsidies and undefined property rights in the absence of free housing market. Housing was part of in-kind worker compensation provided by state-owned enterprises and government agencies. However, there are some indications that the laws of supply and demand have played a role in the allocation of housing even under central planning. Although there was no a regular (money based) housing market, it was possible to exchange apartments through barter, and apartments had their shadow prices. For example, newspapers displayed advertisements offering exchanges. A 3-room apartment in a small Siberian city might be offered for a 1-room apartment in the southern city of Sochi or a 1-room apartment might be offered for a car and a garden plot. Implicit (shadow) housing prices reflected compensating differentials. However, these compensating differentials were likely to be compressed due to residence permits (propiska) and other administrative measures that prevented people from moving freely. The system of propiska was extensively used as an instrument of spatial planning and population allocation policy. As the transition started, the system was abolished, but it is still an issue in two major cities, Moscow and St. Petersburg, that we will consider separately.

The modern Russian housing market began in 1991 with the Soviet Law on Privatization on Housing that allowed for free market trade of houses and established private property rights. The privatization process was slow and, according to the statistical yearbook Goskomstat [21], by the end of 2000 only 47 percent of all housing stock had been privatized. Housing privatization was fulfilled as a free distribution of existing units to residing tenants. Privatization was made voluntary and tenants received an opportunity to privatize their housing for free. Before and after housing privatization, households did not have any rent obligations and paid the same amount of money for repair, maintenance, and utilities regardless of whether they privatized housing or not. 
There were no real incentives to privatize housing unless households were planning to move and sell their units. Housing privatization has been hindered because ownership of a residence may not include ownership of the land on which it stands.

As of 2000, the Russian housing market remained less developed and the transactions costs associated with housing purchases and housing exchanges between cities are still high. However, there is some evidence that even in this environment, compensating differentials for locationspecific amenities can develop. Kolstad, Gorbacheva, Khaleeva, and Shcherbich [31] use data on apartment rents in Moscow, one of the few places where rent data are available, and find that environmental quality is associated with higher rents holding constant the characteristics of the apartment. We will also show that hedonic functions can produce the sensible estimates of compensating differentials and amenity prices 8 years after the beginning of market reforms.

While applying the general compensating differentials framework to Russia, we need to consider several peculiar characteristics of Russian markets and regulations. One of them is the system of government regional wage coefficients that Russia has kept for public workers. These regional wage coefficients provide different levels of compensation for government workers depending on the location of the job. They are not explicitly for cost of living differences, but rather for quality of life differences. As can be seen from Figure 1 that shows the coefficients by region for the year 2000, the compensation for public workers is greater for areas to the north and to the east in Russia where climate is harsher. The value of the regional wage coefficient ranges from 1.0 (base wage and no extra compensation) in central Russia to 3.0 (triple the base wage) in Siberian Chukotka, in northeastern Russia near the Bering Straight.

The fact that compensation for working in areas that are amenity poor has existed for some time makes it more likely that Russian markets generate compensating differentials. Markets will not be limited to climate differences, however, but will consider whatever consumers/workers and 
firms deem important. The presence of government wage coefficients does not change the theory, but we can test to see if their presence has any impact on wages and housing prices. We can see if compensation exists for amenities even after controlling for the regional wage coefficients. In addition, we can examine whether the regional wage coefficients are related to just climate or also to any other amenity variables. Finally, we will be able to compare quality of life rankings that emerge from our market analysis based on compensating differentials with rankings implicit in the government's policy tool, the regional wage coefficients.

When wages and housing prices are freed, observable compensating differentials would be expected to increase and reflect other amenities not reflected in the administratively set regional wage coefficients. The liberalization of labor and housing markets would also increase the variance in the quality of life index across cities and create incentives for people to begin migrating to higher amenity cities. As market development progresses, the differentials and the variance will eventually decrease.

In addition to government compensation policies, several other peculiar Russian features should also be taken into account when estimating the standard model of compensating differentials. Among them are economic volatility (disequilibrium forces), remaining system of residence permits in two largest cities, the low rents-to-housing-value ratio that affects the interest rate, the importance of ethnic conflicts as disamenity, some data problems and other features that will be addressed in the next sections.

\section{Data and Variables}

For the purpose of this study, several data sources are combined into unique linked cityhousehold-employee data that contain detailed information on workers, houses, and city characteristics. The primary data for this study are drawn from the $9^{\text {th }}$ round of the Russian Longitudinal Monitoring Survey (RLMS). The RLMS is a household panel survey based on the 
first national probability sample drawn in the Russian Federation. Rounds 1 through 4 were conducted in 1992 and 1993 using a sample of over ten thousand individuals (Phase I). A new sample (Phase II) was drawn for Round 5 in 1994. This second sample was used subsequently in 1995, 1996, 1998 and 2000-2005.

Questions on individual housing prices were added to the survey beginning with the $9^{\text {th }}$ round of the RLMS conducted between October and December 2000, which is the last year that could be linked to the available city-level data. Therefore, we can use only Round 9 of the RLMS in the estimation of our wage and hedonic models and identify implicit amenity prices using intercity variation in the RLMS. ${ }^{7}$ There were 9,704 individuals who completed the adult (age 14 and over) questionnaire in the $9^{\text {th }}$ round. These individuals come from 39 cities and 119 rural settlements in 32 different oblasts, or regions, in the Russian Federation. The number of employed (employees and self employed) workers residing in urban areas was 3,280. We base our wage analysis on a sample of 3,017 urban workers in the $9^{\text {th }}$ round who have complete information on wages, hours worked, demographic characteristics, occupation, and industry. We base our housing value analysis on a sample of 2,231 households living in cities.

The RLMS provides several individual characteristics such as gender, years of schooling, actual labor market experience, job tenure, marital status, usual monthly hours of work, and average monthly wages. Based on information provided by most working respondents on their job, we were also able to get detailed occupation and industry codes. Data quality can be a

\footnotetext{
${ }^{7}$ While we cannot use panel estimation in the housing equation estimation using the RLMS, we could use panel data for the estimation of the wage equation prior to 2000. We choose not to use data from multiple years to exploit the panel nature of the data for several reasons. First, prices of amenities may be changing over time and it would be difficult to properly account for this in a short panel. Further, if one wanted to do fixed-effect estimation to control for person specific fixed effects, the variation in the quantities of the various amenities may not vary sufficiently over time to allow for identification. Even if there were sufficient variation, it is not clear that one would want to include individual fixed effects, because these fixed effects may themselves capture part of the compensation for amenities in the labor market, especially if unobservably similar workers tend to choose locations with similar amenity bundles. In this case, part of the compensating differential is imbedded in the fixed effects rather than in the estimated implicit amenity prices.
} 
concern in any country, but for transition economies variance in data quality is high. A crucial variable in our hedonic model is the market wage. Actual earnings are problematic as a measure of equilibrium wages in Russia given that many Russian workers have wage arrears (60 percent of RLMS employees reported wage arrears in 1998) and that some actual earnings observations contain several months of back pay while others contain no pay for the current month. Instead, we use the worker's contractual wage, (natural log of) the average monthly wages at the worker's primary job. This wage information was specifically elicited from respondents in the $9^{\text {th }}$ round of the survey. As discussed by Earle and Sabirianova [14], the contractual wage circumvents the wage arrears problem and represents the best available wage measure for our study.

Data on housing prices also present a challenge. The RLMS variable for the price of housing is owner-reported market house value. We do not attempt to use rent data because the rental market was not developed by 2000 for most cities. Our data show that only 6 percent of households rent their residence. Only respondents who reside in their own housing report information on housing value and those values are what we analyze. Figure 2 illustrates large variance of average city housing prices; they range from 37,250 to 947,291 rubles for 39 RLMS cities.

Values reported by owners are reliable in the U.S., except for a tendency of owners who have recently purchased their houses to report values slightly higher than other evidence indicates their houses are worth; see Kiel and Zabel [30]. We assume, for lack of better information, the same to be the case in Russia. We know that a substantial share of Russian households did not report housing values, perhaps because as of yet there is not a general knowledge of market prices due to relatively few transactions in any given area. To correct for any bias in house prices caused by differences between the owners who report and owners who do not report, we estimate a selection equation for reporting as one of the alternatives to our benchmark specification. 
The city-level data on amenities and economic conditions come from the Annual Registries of Russian cities. The city registries contain information from the reports of municipalities submitted to the Russian Statistical Office (Goskomstat) for the period 1994-1999. The data allow us to exploit a variety of relevant city characteristics including total air pollution, amount of sulfur fall-out, effluent of dirty sewage, phone lines, number of physicians, crime rate, share of loss making firms, employment, migration, and development of public transportation. Most variables are taken for the year preceding the individual survey, 1999. For some variables such as pollution, crime rate, and employment change (those with significant missing values, higher measurement error, and stronger time-series fluctuations) we use annual averages for the 1994-1999 period.

As shown in Table 1, some data are not available at the city-level and we use regional variables that come from the 2000 Goskomstat Regional Yearbook, the Practical Science Database, and regional risk indices. These variables include climate variables, the morbidity rate, and an index of ethnic and political risk. The latter variable from a study by Matiyasevich et al. [33] is included because of its high relevance for the quality of life in Russia. The integrated index of ethnic and political risk is comprised of historic conflicts in international relations, religious confession homogeneity, tendency to sovereignty on the national level, emigration of non-native population, historical growth of Cossack settlements, and mass presence of refugees. It ranges from 0 in Kostroma oblast (a region in Central Russia) to 9.388 in the Republic of Dagestan in Northern Caucasus. The highest values are given to regions that are close to Chechnya areas of conflicts. We can see if compensating differences are generated in the areas that are close to actual and potential wars, ethnic conflicts, and terrorism.

Previous studies have shown the importance of commuting time in analyzing the quality of life. The complication is that data on average commuting time is not available for cities outside 
the RLMS data or for the year 2000. Therefore we estimated commuting time equations using Rounds 5-8 (1994-1996, 1998) of the RLMS. Commuting time in hours per week was expressed as a function of demographics (gender, age, and schooling), passengers per capita, and city-level variables measuring the local public transportation system such as types of public transportation, route length, and number of public vehicles. These results are shown in Appendix 2. For comparability purposes, we obtained predicted values for commuting time across 953 cities, all cities for which we have data, using the public transportation and passenger congestion variables. ${ }^{8}$

Table 1 contains the full list of variables used in our analysis, and the descriptions and sources of the variables. These variables were chosen because climate, public services, and environmental quality are theoretically relevant, previous studies of market economies have found them to be important, they are important determinants of the QOL in Russia, and they are the variables for which data are available.

Gyourko and Tracy [24] enrich the model of wages, rents, and amenities by broadening the scope of amenities beyond natural amenities such as climate to include amenities that are locally produced. They explicitly incorporate the local fiscal environment, i.e. publicly provided services and taxes, in their model and find substantial wage differentials as compensation for amenity differences in their analysis of U.S. cities. As Gyourko, Kahn and Tracy [23] show, omitting property taxes will make full implicit prices biased towards more capitalization of locally produced goods into wages and less into housing prices. We have some produced amenities as measured by crime rate, phone lines, commuting time, number of physicians, whether the city is a regional capital, and risk of ethnic unrest and some partly publicly produced amenities such as air pollution and water pollution. However, the property taxes paid by Russian households amount to

\footnotetext{
${ }^{8}$ By not including the demographic variables, we are evaluating the predicted commuting time at a constant set of demographics across cities. The mean values of the demographic variables multiplied by their estimated coefficients
} 
an insignificant portion of the local budget. This will reduce the size of the bias that is due to the omitted property taxes in our model.

Another possible modification to the model of wages, rents, and amenities is to include the consumption of private, locally produced goods excluding housing. Gabriel, Mattey and Wascher [17] incorporate nonhousing, local goods and demonstrate that the compensating differential in the price of local consumption goods becomes a third component of the full price of amenities. They find that the estimates of full implicit prices of some amenities are different when they are based on the three differentials rather than only wages and housing prices. Overall, however, their rankings for the 50 (U.S.) states for the period between 1981 and 1990 based on QOLI with two differentials and their augmented QOLI with three differentials had a Spearman rank correlation equal to 0.9 . We rely on this overall similarity for Russia because we do not have data for prices of local consumption goods excluding housing. As an alternative to our basic specification we do try adding a regional-level variable that measures the minimum income needed for subsistence. The level of subsistence is highly correlated with consumer prices and excludes housing prices. Recently, Gabriel and Rosenthal [18] develop the model of wages, rents, and amenities model further to estimate the "quality of the business environment," i.e., the value of location specific amenities to firms. For a pure consumption amenity, they start with the fact that housing (land) prices and wages are both costs to firms and show that to get a measure of the value of the amenity to firms, the compensating wage differential is added to (not subtracted from) the housing price differential. They use the value to firms along with the value to consumers/workers to analyze migration and the growth and composition of 37 cities in the U.S. over the period 19771995. We focus on the location decisions and quality of life of consumers/workers rather than

in the commuting time equation is subsumed into the constant terms of the estimated wage and housing hedonic equations. 
firms, and therefore use the more traditional formulation of Rosen [39] and Roback [38] using data from the RLMS, city registries, and other available Russian sources.

\section{Estimated Implicit Prices, Government Regional Policy, and Quality of Life}

\section{a. Labor and Housing Markets and Implicit Prices}

To obtain the full-implicit prices of location-specific amenities given in (4), we begin by estimating a reduced form of wage and housing prices hedonic equations:

$$
\begin{aligned}
& \ln w_{i j}=\beta_{0}+\beta_{1} X_{i j}+\beta_{2} A_{j}+\beta_{3} D_{j}+\varepsilon_{i j} \\
& \ln p_{h j}=\gamma_{0}+\gamma_{1} Z_{h j}+\gamma_{2} A_{j}+\gamma_{3} D_{j}+u_{h j} \\
& \varepsilon_{i j} \sim N\left(0, \sigma_{\varepsilon}^{2}\right), u_{i j} \sim N\left(0, \sigma_{u}^{2}\right),
\end{aligned}
$$

where $X_{i j}$ is a vector of individual characteristics of worker $i$ residing in location $j, Z_{h j}$ is a vector of housing characteristics of residence $h, A_{j}$ is a vector of location amenities, $D_{j}$ are location controls for economy disequilibrium; $\beta_{2}$ and $\gamma_{2}$ will give us a reduced-form estimate of $\mathrm{d} w_{k} / \mathrm{d} a_{k}$ and $\mathrm{d} p_{k} / \mathrm{d} a_{k}$, respectively in (4). We assume $\varepsilon_{i j}$ and $u_{h j}$ to be independent at first and then we will relax this assumption and estimate (6) as the system of simultaneous equations, allowing for correlation between $\varepsilon_{i j}$ and $u_{h j}$.

First, we estimate a reduced-form wage equation as a function of individual characteristics $\left(X_{i j}\right)$, location amenities $\left(A_{j}\right)$, and controls for labor market disequilibrium $\left(D_{j}\right)$. Because our model assumes that workers are homogenous, the implied equilibrium wage equation would include only location amenities. However, empirically we must control for worker heterogeneity, so we include a series of individual characteristics. Similarly, our model assumes that the labor market is in equilibrium. In order to control empirically for potential disequilibrium situations, we also include measures of annual employment change and the local share of firms making losses.

As in all of the statistical estimates reported in the paper, we use the STATA software package. Robust standard errors from the Huber-White estimator are used to calculate standard 
errors with clustering by the 39 cities in the RLMS. The wage equation results are reported in Table 2, along with means, standard deviations, and minimums and maximums of the variables used in the estimation. The estimates in Table 2 are performed without RLMS sample weights. The weights include many of the same variables we already include in our model, so any gain will be mostly from improved efficiency. However, we already employ the Huber-White estimator to produce robust standard errors and account for a general form of heteroscedasticity. Later in the paper, we compare the quality of life rankings that we obtain using the estimates reported with those obtained using sample weights.

In general, the results for the individual characteristics are quite consistent with what one would find for a typical Mincer earnings equation. There are positive returns to schooling, and quadratic experience-earnings and tenure-earnings profiles. The estimated returns to schooling are below typical recent estimates for Russia and other transition economies (see Fleisher, Sabirianova Peter and Wang [16]) since we have a more extensive set of individual and location controls which are positively correlated with years of schooling. Without occupation dummies and amenity variables, the estimated returns to schooling would fall in the same range as those typically obtained in the U.S. ${ }^{9}$ and would be higher than those reported by Brainerd [7] for 1993-94, using a different Russian data source, monthly cross-section household surveys conducted by the AllRussian Center for Public Opinion Research. Our estimated experience and tenure profiles are slightly more concave than the experience profiles reported by Brainerd [7], perhaps because we use actual rather than potential years of experience. These profiles are flatter and less concave than those typically estimated in the U.S.

The wage effects for the 11 amenity variables are jointly significant; the $F(11,38)=9.51$.

\footnotetext{
${ }^{9}$ See Barron, Berger, and Black [3] and Card [9] for some typical cross-section estimates using Census and Current Population data.
} 
The theoretical model makes clear that it is the full compensation through both the housing and labor markets that ultimately matters for determining quality of life differences. Nonetheless, it is interesting to note that the coefficients for most of the amenity variables are statistically significant and have the sign that would be expected if all compensation were through the labor market.

The disequilibrium variables suggest that in areas in which firms are making losses, wages are lower, but that increased employment is positively related to wages. The two disequilibrium variables are jointly significant in the determination of wages; $F(2,38)=12.3$ and suggest it is important to include these controls in our hedonic model of Russian wage determination. ${ }^{10}$

Next, we turn to the estimation of the housing hedonic model. The set of housing characteristics is less than ideal in that there is not information on the age of the structure, for example. As shown in Table 3, the results for the structural characteristics that we do have seem reasonable. The amenity variables are jointly significant; $F(11,38)=19.63$. However, many of the individual coefficients have low $t$-values. Some coefficients have unexpected signs if all compensation came through the housing market, but it is the total compensation through both markets that matters. ${ }^{11}$ The two disequilibrium variables are jointly significant; $\mathrm{F}(2,38)=10.94$. Larger employment decline and higher shares of firms losing money are associated with lower housing prices.

In Table 4, we combine the estimated wage and housing price differentials into annual full implicit prices per household using Eq. 4 evaluated at the means of wage, number of workers, and housing value of the sample, assuming a 4.35 percent interest rate for converting house value to annual rent. $^{12}$ This calculation involves multiplying the negative of the parameter estimate in the

\footnotetext{
${ }^{10}$ Such controls for disequilibrium forces have also been used in wage and housing hedonics using U.S. data; see, for example, Berger and Blomquist [5].

${ }^{11}$ Because the full implicit price shown in equation 4 above calls for the total differential of the effect of an amenity, we estimate both wage and housing price equations in reduced form.

${ }^{12}$ This rate is found by dividing the predicted annual rent by the average house price for 2000 , where rent is predicted from regression of monthly rental payments of tenants on characteristics of rented residence.
} 
log wage equation by the mean wage to convert the estimated effect into rubles and then multiplying by 12 and 2.65 full-time equivalent workers per household to convert to annual household compensation in the labor market. The labor market compensation is added to the housing market compensation which is simply the housing market estimated parameter multiplied by the mean housing value to convert to rubles, and by 0.0435 to get an imputed annual housing expenditure. A negative full implicit price means that a characteristic is a disamenity while a positive price is an amenity.

The full implicit prices based on the wage equation estimates shown in Table 2 and the housing value estimates shown in Table 3 are reported in the first column of Table 4 and under OLS Benchmark. The implicit prices are all of the expected sign and all but air pollution and commuting time are statistically significant at the 10 percent level or higher. ${ }^{13}$ Phone lines, number of physicians, and location in a capital city are amenities and the remaining variables are disamenities. The full implicit prices are expressed in thousands of rubles per year.

In order to get a better idea of the amount of compensation involved given the different scaling of the units of the different amenities, the last column of Table 4 shows the compensation required for one standard deviation change in the amenity or disamenity from its mean value for the OLS benchmark results. This column shows the amount in thousands of rubles that the average Russian household would be willing to pay for one standard deviation increase in the quantity of local amenities and would be willing to accept for one standard deviation increase in

\footnotetext{
${ }^{13}$ The standard errors on the full implicit prices are obtained by taking a linear combination of the standard errors in the wage and housing price hedonic equations, with the same weights as those used to calculate the full implicit price and with the assumption that the covariance between the partial prices is zero. This is the same approach used by Blomquist, Berger, and Hoehn [6]. The full implicit price on the capital city dummy is calculated using the transformation proposed by Halvorsen and Palmquist [25]. Full implicit prices based on seemingly unrelated regression, which take into account correlations in the errors, are reported in Table 4.
} 
the quantity of local disamenities. ${ }^{14}$ One standard deviation changes in heating degree days, total precipitation, and crime rate produce the largest implicit annual compensation in the housing and labor markets. The amounts are 7,496, 6,695, and 9,371 rubles per year per household, respectively. These compensation amounts are sizable compared to the mean annual salary of 23,940 rubles for a worker. For a one standard deviation improvement in the crime rate, the compensation for the average household is 39 percent of the average worker's salary; it is 15 percent of the average household's annual earnings.

Full implicit prices using four alternative methods of estimation are also reported in Table 4. The Heckman column shows full implicit prices based on a housing value regression that accounts for the fact that a significant number of respondents did not report a housing value. The regression estimates are provided in Appendix 3. The Heckman maximum likelihood selection model has two equations: an equation explaining whether a respondent reports a housing value and a second equation in which the log of housing value is a function of housing characteristics, location amenities, disequilibrium variables, and the inverse Mills ratio. The model is identified by including demographic characteristics of the respondent in the selection equation such as gender, age dummies, level of education, and computer skills. Demographic characteristics that are included in the selection equation may be correlated with knowledge of the housing market and thus the propensity to report a housing value. We find that older respondents and less educated individuals, who may have less knowledge of the housing market, are less likely to report a housing value. Those with computer skills are more likely to report a housing value. In the housing hedonic, the estimated inverse Mills ratio $(\lambda)$ has a negative coefficient, but it is not statistically significant. This implies that there is a weak indication that holding housing

\footnotetext{
${ }^{14}$ The hedonic estimates are only strictly valid for small changes in the quantities of amenities and disamenities. However, the vehicle of considering one standard deviation changes has been used often in the literature to illustrate the relative sizes of the implicit compensations for various amenities. Also, see footnote 6 about sorting.
} 
characteristics, location amenities, and disequilibrium conditions constant, a random person from the population would report a higher housing value than those who actually report, but the difference is not significant. The end result is that the full implicit prices based on the Heckman specification are similar to the estimated prices for the OLS benchmark.

Table 4 also reports the full implicit prices estimates using the feasible generalized least squares method (FGLS) to address the potential heteroskedasticity of the error term in both equations. Although standard tests did not indicate the presence of heteroskedasticity in the wage equation, the modified White test (but not a Breusch-Pagan test) detected it in the housing equation; $F(2,1486)=28.96)$. We use FGLS to obtain more efficient estimates when the form of heteroskedasticity is unknown. These results too are very similar to the OLS-estimated prices.

In all three sets of estimates reported above, we assumed a zero covariance between partial prices in calculating the standard errors of full implicit prices. To relax this assumption, we created a partially overlapping sub-sample that matches houses and heads of households (defined as the household member with largest labor earnings) and applied seemingly unrelated estimation (SUEST). Based on separate estimates of two hedonic equations, SUEST generates a simultaneous covariance matrix for pairs of regressions allowing for computing robust/clustered standard errors for the linear combination of coefficients with non-zero covariance (the "lincom" command in Stata). Despite a significant reduction in the sample size of wage earners, the SUEST results reported in Table 4 are similar to the OLS-estimated prices for the full sample except for air pollution which switches sign but has low $t$-values in both specifications.

One valid concern with a separate estimate of two hedonic equations is the assumption of no cross-equation correlation of error terms. The errors could be correlated due to simultaneity of decisions regarding housing and labor market participation and also due to omitted variables that are common in both hedonic equations (for example, unobserved location-specific amenities); thus 
leading to the biased estimates of partial and full implicit prices. To address this concern, we apply the Zellner's method of seemingly unrelated regressions (SUREG), which allows for correlated errors between equations. The method can be implemented on the fully overlapping sample of working heads of households, for which the average house value and earnings are nonmissing. Our sample is reduced to 1087 observations. Another disadvantage of this method is that clustered standard errors are not allowed within the SUREG procedure, but this does not affect the magnitude of coefficients. Compared to the estimated prices for the OLS benchmark, the full implicit price for home phone lines and ethnic-political risk grow, and the price for doctors shrinks (Table 4).

In sum, despite the different estimation methods and substantial differences in samples and sample sizes, the estimated implicit prices shown in Table 4 are quite consistent. ${ }^{15}$ Regardless of the method, we find that compensation exists for the 11 amenities across cities in Russia.

\section{b. Government Regional Wage Coefficients and Implicit Market Prices}

Our initial formulation of the wage and housing price hedonic model omitted the government regional wage coefficient. However, the government regional wage coefficients were designed to compensate for regional climate differences. It is interesting to determine how much compensation for location amenities exists in Russian wage and housing markets after controlling for the regional wage coefficients or whether the market compensation replicates the kind of compensation that was in place even during the Soviet period. ${ }^{16}$

Table 5 shows the wage differentials after including the government regional wage coefficient variable. As expected, this variable is highly significant: areas with higher values for

\footnotetext{
${ }^{15}$ The correlation in QOLI ranking of cities with the OLS Benchmark ranking is at least 0.9 for these alternative methods, as reported in Table 6 below. The complete estimates of wage and housing value hedonic equations for each estimation procedure are available upon request.

${ }^{16}$ The government regional wage coefficients used in this paper are apparently very similar in magnitude to those used during the Soviet period.
} 
the regional wage coefficient (worse climates) have higher wages. Now, when heating degree days and total precipitation are taken together, their contributions are statistically insignificant at normal levels, $\mathrm{F}(2,38)=1.53$. However, the amenities are still jointly statistically significant, $\mathrm{F}(11,38)=8.66$. The government wage coefficient reduces the remaining compensation through the labor market, but it does not eliminate it. The pattern is not as clear as for the housing value equation, nor should we expect it to be. The government regional wage coefficients were designed to reflect compensation in the labor market, not the housing market. Some of the estimated amenity coefficients become insignificant after the introduction of the government wage coefficient, others become significant. However, the amenities are still jointly significant, $\mathrm{F}(11,38)=11.37$. While some of the compensation generated by the market duplicates compensation reflected in the government regional wage coefficients, there is additional market compensation taking place.

\section{c. Quality of Life across Russian Cities}

We are now in a position to calculate quality of life index values. We use the full implicit prices for the 11 amenities that were estimated with the RLMS data on wages and house values with matched administrative data from 39 cities. The full implicit prices for the OLS benchmark specification shown in Table 4 are used to weight the bundle of amenities in each city to produce a quality of life index value. Given that the RLMS cities are fairly representative of cities throughout Russia, we generate QOLI's for 953 cities in the Russian Federation using the parameter estimates obtained from the RLMS data. ${ }^{17}$ Selected results are described here, but a complete ranking of all cities is available upon request.

\footnotetext{
${ }^{17}$ RLMS employs a multi-stage probability sample. At the national level, selected municipalities represent reasonably well the Russian urban population. Appendix 1 provides a comparison of the amenity levels in the 39 RLMS cities with the full sample of 953 cities. There are insignificant differences in the mean values of climate variables, air pollution, sulfur fall-out, morbidity rate, ethnic-political risk, and government regional wage coefficients. At the same
} 
The index values are most easily interpreted when comparing cities with one another. The index values are denominated in thousands of year 2000 rubles per year. The estimated minimum QOLI value is added to each index value so that all index values are positive and the lowest QOLI value is zero. The range in the quality of life index across the 953 cities is 229,000 rubles, several times the average annual wage. This variation is a much larger than the variation found by Blomquist, Berger, and Hoehn [6] across their sample of 253 U.S. counties, perhaps reflecting the greater variability in the basket of amenities in Russia relative to the U.S. A one standard deviation improvement in the QOLI in Russia is approximately 30 percent of a typical household's annual earnings $(19,296 / 63,454=0.30)$. This amount is an order of magnitude greater than the 3 percent that was found for the U.S. $(667 / 20,053=0.03)$. The amenities bundle in the two studies is different, but given the higher incomes in the U.S., this difference in the premium for a one standard deviation improvement is an indication that the greater variation in the QOLI is due to the greater variation in the amenity factors rather than variation in the prices.

Figure 3 provides a graphical depiction of the quality of life index values by region. The regional values are population-weighted values of the QOLI values for the cities in the region. As such, they represent a regional urban average of quality of life. In general, regions with cities with higher quality of life appear to be in the southern and European region of Russia. There is variation within regions. For example, within the Sverdlosk region in the Urals, the QOLI varies from a low of 146 thousand rubles per year in Sysert, ranked 925, to a high of 193 thousand rubles per year in the capital of Yekaterinburg, ranked 191. Among the top twenty places ranked by QOLI are five large cities (Voronezh, Stavropol, Astrakhan, Volgograd, and Saratov) and several renowned spa resorts such as Essentuki, Kislovodsk, and Zheleznovodsk. All are located in the southern part of Russia. At the bottom of the ranking are cities such as Norilsk (953) that are 
north of the Arctic Circle. Norilsk is a Siberian city that once had a forced labor camp and is known for cold, severe pollution due to smelting, and acid rain.

The two largest cities in our ranking are Moscow (224) and St. Petersburg (400). These rankings appear low given that there is excess demand for available residence permits or propiskas in these two cities, suggesting that they are desirable places to live. This localized disequilibrium for Moscow and St. Petersburg makes it difficult for us to get true quality of life rankings for these two cities. First, the rationing of residence permits means that housing prices will not get bid up high enough and labor supply will not increase and wages will not be bid down enough to reflect quality of life in these two cities. However, this problem should not be a very large one for our wage and housing parameter estimates since Moscow and St. Petersburg together only make up a small portion of the full RLMS sample. However, the ranking for Moscow and St. Petersburg are still problematic under the system of rationed residence permits if their attractiveness is unique and cannot be accounted for by typical variables in quality of life indexes. In this case, an appropriate strategy would be to include dummy variables for Moscow and St. Petersburg, but the system of residence permits would prevent us from estimating the full values of the unique amenities in those two cities. We have estimated the wage and housing equations with dummy variables for Moscow and St. Petersburg and find, as reported in Table 6, that the QOL ranking with our base ranking is quite high, 0.98 .

We have also calculated alternative QOLIs to check the sensitivity and robustness of our original ranking. Table 6 reports correlations of these alternative indexes and the resulting rankings with our original index and ranking. Rows 1 and 2 show correlations with QOLIs after controlling for the government regional wage coefficient, 0.82 for the RLMS cities and 0.86 for the full sample of 953 cities. Interestingly, as shown near the bottom of the table, the government 
regional wage coefficients and our QOLI have a simple correlation of -0.66 for the RLMS cities and -0.39 for the full sample. They would be perfectly negatively correlated if the government compensation and market compensation were equal for the same amenities.

Rankings with dummy variables for Moscow and St. Petersburg, a set of alternative amenity variables described in Table 5, inclusion of the cost of subsistence level in each city, observations weighted by RLMS weights, and wages actually received last month, all are highly correlated with the ranking using our base hedonic equations (0.90-1.00). The QOLIs and rankings obtained by different estimation methods (such as Heckman maximum likelihood, FGLS, and SUREG) are also very highly correlated with the OLS-based QOLI (0.91-1.00).

Gyourko, Kahn, and Tracy [23] argue that if the observed amenities model is used, as in this paper, then it should be compared to the group effects model under the assumption that errors due to unaccounted unobservables in wage and housing price equations are caused primarily by omitted amenities rather than omitted worker or house characteristics. Gyourko and Tracy [24] find that group effects can matter for specific amenity values and can matter in rankings too because the standard errors on the QOLI values can be large. Gabriel, Mattey, and Wascher [17] use an observed amenities model and compare it to a group fixed effects model for the 50 states and find there is not much difference in the rankings (the Spearman rank correlation is 0.8).

Given these previous studies, it is worth comparing the rankings that would be obtained from a group effects model from those that we obtain from our observed amenity model. It is only possible to estimate city fixed effects for the 39 cities in the RLMS sample and not for the other cities in the full city sample. We restrict our comparisons to these 39 cities. Another complication is that our two disequilibrium variables vary only city to city and thus drop out of the city fixed effect model. We recalculate the quality of life index to include the two disequilibrium variables and correlate the revised index with the city fixed effects. The resulting correlation coefficients 
are 0.47 for the simple correlation and 0.61 for the Spearman rank correlation. While these correlations are lower than the one obtained by Gabriel, Mattey, and Wascher (2003), it does show that the alternative sets of rankings are fairly highly related to one another. We would not expect the correlation to be one because variables such as building age, housing condition, and outside space are not included in the housing price equation due to unavailability. This matters because differences in these housing structure characteristics erroneously will be attributed to differences in quality of life using the group effects approach. In addition, our comparison points to the fact that a pure comparison is not possible using our models because of the presence of variables to control for disequilibrium forces in the housing and labor markets.

\section{Migration and Quality of Life}

Despite the nature of transition from central planning to a market economy in Russia, we have substantial evidence that equilibrium forces exist. The estimated wage and housing price equations show that wages depend on worker and job characteristics and housing price depend on house characteristics in expected ways. Location specific amenities generate compensating differentials in both wages and housing prices. This result is consistent with the prediction of the equilibrium framework. These results come from equations that partly control for disequilibrium by including two variables in our equations, city annual employment change and share of firms in the city that are making losses.

Migration is important in the equilibrium framework in that migration of some consumer/workers and firms is necessary to achieve spatial equilibrium. Migration is a real phenomenon in the transition economy of Russia. Andrienko and Guriev [1] analyze gross regionto-region migration flows in Russia. They report that total officially registered internal migration is approximately 2 percent per year during the 1990s. This migration rate is considerably lower 
than the migration rates of developed, market economies. ${ }^{18}$ Their analysis of migration flows during the period 1990-1999 shows that job opportunities matter, and that climate and local public goods matter as well. This finding gives more credibility to our estimates of amenity compensating differentials in Russian in that migration is occurring and is influenced by location specific amenities.

Our calculations from the Annual Registries of Russian Cities show higher level of internal migration in Russia. During the 1994-1999 period, at least 3 percent annual changes in population due to migration are estimated for 73.3 percent of the cities, at least 5 percent annual changes for 56.6 percent of the cities, and at least 10 percent annual changes for 27.7 percent of the cities. Even these rates, however, are lower than the migration rates of developed, market economies.

The existence of migration does not necessarily imply disequilibrium. Life cycle motivation for migration can be thought of as an equilibrium phenomenon. As households experience anticipated changes in income, they will anticipate relocating to areas that offer a bundle of amenities that more closely matches their new demands. As households anticipate changing their participation in the labor market, say through retirement, they will relocate to areas that more closely match their demands; see Linneman and Graves [32] and Gyourko, Kahn, and Tracy [23]. Thus, migration can be related to equilibrium differences in quality of life as shown by Berger and Blomquist [5] using U.S. data. Similarly, Brown [8] provides some evidence that aggregate region-to-region migration in Russia is related to air pollution and temperatures, which are components of typical quality of life indexes. In the last two rows of Table 6, we show that our quality of life index is positively correlated with net migration into Russian cities. In other

\footnotetext{
${ }^{18}$ The official data used by Andrienko and Guriev [1] may well understate the actual amount of migration in Russia. Almost half of the respondents in the RLMS report that they have lived for 6 consecutive months or more in a different location since age 14 .
} 
words, cities with higher measured quality of life attract more in migration, consistent with equilibrium movement toward high quality of life areas. ${ }^{19}$

\section{Conclusions}

This paper uses data from the Russian Longitudinal Monitoring Survey (RLMS) and administrative sources to examine compensating differentials for location-specific amenities in the labor and housing markets. We find that there is compensation generated in labor and housing markets for differences in amenities across cities in Russia. This result may be surprising given the relatively recent transition to a market economy. However, our results suggest that even nascent market economies are capable of generating compensating differentials. Our results are consistent with available evidence on region-to-region migration in Russia. While migration rates in Russia are below those in developed, market economies, they do appear to be sensitive to amenity variation across regions. Apparently the migration that does occur is enough to generate inter-city variation in wages and housing prices due to inter-city variation in amenities. The estimated wage and housing premiums are used to calculate a quality of life index across cities in the Russian Federation for the year 2000, the year for which we have complete data. In general, quality of life is higher in cities in southern and European areas of Russia.

Perhaps one of the reasons that market generated compensating differences have appeared relatively quickly in Russia is that there was a long history in the Soviet era of government mandated compensating differentials intended to offset climate differences. These government regional wage differences still exist in the public sector. We find that after controlling for these mandated differences in the public sector, we still are able to estimate compensating differentials

\footnotetext{
${ }^{19}$ Mueser and Graves (1995) introduce moving costs to a model of compensating differentials to develop a model of migration. They emphasize that migration results from changes that disturb the equilibrium wages, rent, and amenities. Applied to Russia, their model implies that migration occurs because of changes in policy that reduce moving costs, and changes in amenities, and income.
} 
and generate quality of life measures. Thus, while government planners have been able to dictate some compensation for quality of life differences, there are still substantial compensating differentials on top of the government regional wage differentials. This important result of market forces is readily observable in a country such as Russia in which the transition to a market is far from complete. As transition continues, quality of life in Russia can be expected to change. Kahn (2003) found that urban environmental quality has improved in Eastern Europe during transition and amenity bundles in Russian cities can be expected to change as environmental quality, crime and other factors change. Valuations can change. Costa and Kahn (2003) find evidence that the prices of climate and job fatality risk have risen over time in the U.S. and values can be expected to change in Russia during transition. Policy decision makers will want to acknowledge the dynamic nature of quality of life and anticipate change. Future changes aside, the many difficulties that Russia has experienced have not been enough to prevent market compensation for a broad array of amenities from taking hold in labor and housing markets at a fairly early phase of transition.

\section{References}

[1] Y. Andrienko, S. Guriev, Determinants of interregional mobility in Russia: evidence from panel data, Economics of Transition 12 (2004) 1-27.

[2] P. Bajari, M.E. Kahn, Estimating housing demand with an application to explaining racial segregation in cities, Journal of Business and Economic Statistics 23 (2005) 20-33.

[3] J.M. Barron, M.C. Berger, D.A. Black, On the Job Training, Upjohn Institute for Employment Research, Kalamazoo, MI, 1997.

[4] P.E. Beeson, R.W. Eberts, Identifying productivity and amenity effects in interurban wage differentials, Review of Economics and Statistics 71 (1989) 443-452.

[5] M.C. Berger, G.C. Blomquist, Mobility and destination in migration decisions: the roles of earnings, quality of life, and housing prices, Journal of Housing Economics 2 (1992) 37-59.

[6] G.C. Blomquist, M.C. Berger, J.P. Hoehn, New estimates of quality of life in urban areas, American Economic Review 78 (1988) 89-107. 
[7] E. Brainerd, Winners and losers in Russia's economic transition, American Economic Review 88 (1998) 1094-1116.

[8] A.N. Brown, The Economic Determinants of Internal Migration Flows in Russia During Transition, William Davidson Working Paper Number 89, William Davidson Institute, University of Michigan, 1997.

[9] D. Card, The causal effect of education on earnings, in: O. Ashenfelter, D. Card (Ed.), Handbook of Labor Economics, Volume 3A, Elsevier, Amsterdam, 1999, pp.1802-1863.

[10] R.T. Carson, Jr., Contingent valuation, resources and environmental, in: N.J. Smelser, P.B. Baltes (eds.) International Encyclopedia of the Social and Behavioral Sciences, Volume 19, Elsevier Science, Amsterdam, 2001, pp. 13272-5.

[11] K.Y. Chay, M. Greenstone, Does air quality matter? evidence from the housing market, Journal of Political Economy 113 (2005) 376-424.

[12] D.L. Costa, M.E. Kahn, The rising price of nonmarket goods, American Economic Review 93 (2003) 227-232.

[13] R. di Tella, Rafael, R.J. MacCulloch, and A.J. Oswald, "Preferences over inflation and unemployment: evidence from surveys of happiness, American Economic Review 91 (2001) 335340 .

[14] J. Earle, K. Sabirianova, How late to pay? understanding wage arrears in Russia, Journal of Labor Economics 20 (2002) 661-707.

[15] S. Fischer, R. Sahay, Taking stock, Finance \& Development (International Monetary Fund) 37 (2000) 2-6.

[16] B. Fleisher, K. Sabirianova Peter, X. Wang, Returns to skills and the speed of reforms: evidence from Central and Eastern Europe, China, and Russia, Journal of Comparative Economics 33 (2005) 351-370.

[17] S.A. Gabriel, J.P. Mattey, W.L. Wascher, Compensating differentials and evolution of quality of life among U.S. states, Regional Science and Urban Economics 33 (2003) 619-649.

[18] S.A. Gabriel, S. Rosenthal, "Quality of the business environment versus the quality of life: do firms and households like the same cities?" Review of Economics and Statistics 86 (2004) 438-444.

[19] Goskomstat, The Annual Registries of Russian Cities, 1994-1999. Database.

[20] Goskomstat, Regions of Russia 2000, Goskomstat, Moscow, 2000.

[21] Goskomstat, Statistical Yearbook of Russia 2001, Goskomstat, Moscow, 2001. 
[22] M.J. Greenwood, G.L. Hunt, D.S. Rickman, G.I. Treyz, Migration, regional equilibrium, and the estimation of compensating differentials, American Economic Review 81 (1991) 1382-1390.

[23] J. Gyourko, M. Kahn, J. Tracy, Quality of life and environmental comparisons, in: E.S. Mills, P. Cheshire (Eds.), The Handbook of Applied Urban Economics, North-Holland, Amsterdam, 1999.

[24] J. Gyourko, J. Tracy, The structure of local pubic finance and the quality of life, Journal of Political Economy 99 (1991) 774-806.

[25] R. Halvorsen, R. Palmquist, The interpretation of dummy variables in semilogarithmic equations, American Economic Review 70 (1980) 474-475.

[26] G. Heal, B. Kristöm, National income and the environment, in: K-G Mäler, J.R. Vincent (Eds.), Handbook of Environmental Economics, Volume 3, North Holland, Amsterdam, 2005.

[27] J.P. Hoehn, A. Randall, The effect of resource quality information on resource injury perceptions and contingent values, Resource and Energy Economics 24 (2002) 13-52.

[28] M.E. Kahn, New evidence on Eastern Europe's pollution progress, Topics in Economic Analysis and Policy 3 (2003) Article 4, http://www.bepress.com/bejeap/topics/vol3/iss1/art4

[29] A.B. Khakhalin, Analysis and Evaluation of Land Reforms and Land Privatization in Cities, Institute of Urban Economics, 2004 (in Russian).

http://www.urbaneconomics.ru/texts.php?folder id=80\&mat id=99

[30] K.A. Kiel, J.E. Zabel, The accuracy of owner-provided house values: the 1978-1991 American housing survey, Real Estate Economics 27 (1999) 263-298.

[31] C.D. Kolstad, E. Gorbacheva, J. Khaleeva, S. Shcherbich, Environmental Economics in Russia: Valuation and Regulatory Distortions, New Economic School, Moscow, 1998.

[32] P. Linneman, P.E. Graves, Migration and job change: a mulitnomial logit approach, Journal of Urban Economics 14 (1983) 263-279.

[33] T. Matiyasevich, N. Mogel, S.A. Nagaev, M. Rossmann, L.I. Smirnych, A. Worgottern, Russia: Regional Risk Rating, Bank Austria AG, Vienna, 1998.

[34] P.R. Mueser, P.E. Graves, Examining the role of economic opportunity and amenities in explaining population redistribution, Journal of Urban Economics 37 (1995) 176-200.

[35] W.D. Nordhaus, New directions in national income accounting, American Economic Review 90 (2000) 259-263.

[36] W.D. Nordhaus, J. Tobin, Is growth obsolete? in: Economic Growth, National Bureau of Economic Research, New York, 1972.

[37] Practical Science Database (PSD) (available at http://www.sci.aha.ru/cgi-bin/regbase.pl) 
[38] J. Roback, Wages, rents, and the quality of life, Journal of Political Economy 90 (1982) 12571278 .

[39] S. Rosen, Wage-based indexes of urban quality of life, in: P. Mieszkowski, M. Straszheim (Eds.), Current Issues in Urban Economics, Johns Hopkins University Press, Baltimore, MD, 1979.

[40] Russian Longitudinal Monitoring Survey (RLMS), 1994-1996, 1998, 2000 (available at http://www.cpc.unc.edu/projects/rlms). 
Table 1: Variables and Data Sources

\begin{tabular}{|c|c|c|}
\hline Variable Name & Variable Description & Source \\
\hline \multicolumn{3}{|c|}{ Housing model variables } \\
\hline \multicolumn{3}{|l|}{ Main regression } \\
\hline Log of housing prices & Log of housing market value, rubles & RLMS2000 \\
\hline Living space & Living space (rooms) in square meters & RLMS2000 \\
\hline Share of non-living space & Share of non-living space (kitchen, bathroom, hall, etc.) in the total housing space & RLMS2000 \\
\hline Privatized housing & 1 if housing is privatized; 0 otherwise & RLMS2000 \\
\hline Central heating & 1 if central heating system; 0 otherwise & RLMS2000 \\
\hline Central water supply & 1 if central water supply; 0 otherwise & RLMS2000 \\
\hline Hot water supply & 1 if hot water supply; 0 otherwise & RLMS2000 \\
\hline Piped gas & 1 if piped gas; 0 otherwise & RLMS2000 \\
\hline Central sewerage & 1 if central sewerage system; 0 otherwise & RLMS2000 \\
\hline Home phone & 1 if family has phone; 0 otherwise & RLMS2000 \\
\hline \multicolumn{3}{|c|}{ Additional variables in the selection probit equation } \\
\hline Reported housing value & 1 if respondent reported the approximate market value of housing; 0 otherwise & RLMS2000 \\
\hline Female & 1 if female; 0 if male & RLMS2000 \\
\hline Age categories & Five age categories: $15-24 ; 25-34 ; 35-44 ; 45-54 ; 55+$ (omitted) & RLMS2000 \\
\hline Education categories & $\begin{array}{l}\text { Five education categories: elementary (omitted); secondary, vocational; technical; } \\
\text { university }\end{array}$ & RLMS2000 \\
\hline Computer skills & 1 if respondent has ever used a computer; 0 otherwise & RLMS2000 \\
\hline \multicolumn{3}{|c|}{ Wage model variables } \\
\hline Log of monthly wages & Log of average monthly wages at the primary job, rubles & RLMS2000 \\
\hline Log of monthly hours & Log of usual hours of work per month at the primary job & RLMS2000 \\
\hline Female & 1 if female; 0 if male & RLMS2000 \\
\hline Married & 1 if now married; 0 otherwise & RLMS2000 \\
\hline Years of schooling & Highest year of school attended & RLMS2000 \\
\hline Actual experience & Years of actual labor market experience & RLMS2000 \\
\hline Experience squared & Years of actual labor market experience squared & RLMS2000 \\
\hline Tenure & Years of work at the same enterprise & RLMS2000 \\
\hline Tenure squared & Years of work at the same enterprise squared & RLMS2000 \\
\hline Self-employed & $=1$ if self-employed; 0 if employees & RLMS2000 \\
\hline
\end{tabular}



machine-building; wood processing; light and food industries; agriculture (omitted); transportation and communications; construction; trade; finance and commerce; municipal utilities; health; education, culture, and art; public administration; and other industries

Occupation dummy variables

8 occupation dummies include officials and managers; professionals; associate professionals and technicians; clerks; service workers; craft workers; operators and assemblers; military specialist; elementary occupations (omitted)

\section{City-level variables}

\section{City (municipal) amenities}

\section{Air pollution}

Sulfur fall-out

Water pollution

Total phone lines

Home phone lines

Doctors

Commuting time

Crime rate

Capital city

\section{City disequilibrium variables}

Share of loss-making firms

Employment change

Average mobility change

\section{Regional amenities}

Temperature in warm period Heating degree days (cold)

Total precipitation

Precipitation in cold period

Morbidity rate

Ethnic and political risk

Level of subsistence
Air pollution, tons per Ha, 1994-1999 average

Fall-out of sulfurous anhydride, tons per Ha, 1994-1999 average

Effluent of dirty sewage, thousands cubic m per Ha, 1994-1999 average

Number of phone lines per capita, 1999

Number of home phone lines per capita, 1999

Number of physicians per 100 population, 1999

Predicted commuting time (calculated by the authors from the estimated commuting time equation)

Number of registered crimes per 1,000 population, 1994-1999 average

1 if central city of a region; 0 otherwise

Share of loss-making firms, 1999

Annual employment change, percent, 1994-1999 average

Annual change in population due to migration per 1,000 population, 1994-1999 average

\section{Regional-level variables}

Sum of temperature in warm period, $>10 \mathrm{C}$

Sum of heating degree days, $<0 \mathrm{C}$

Sum of precipitation in warm and cold periods, $\mathrm{mm}$

Sum of precipitation in cold period, $\mathrm{mm}$

Morbidity rate or number of illnesses per capita, 1999

Index for ethnic and political risk, 1998: integrated index comprised of historic conflicts in inter-national relations, confession homogeneity, tendency to sovereignty on the national level, emigration of non-native population, historical growth of Cossack settlements, and mass presence of refugees

Minimum amount needed for subsistence, thousand rubles per month, 1999
GKSCITY

GKSCITY

GKSCITY

GKSCITY

GKSCITY

GKSCITY

Authors

GKSCITY

Authors

GKSCITY

GKSCITY

GKSCITY

PSD

PSD

PSD

PSD

GKS2000

RISK1998

GKS2000 


\section{Table 1: Variables and Data Sources (continued)}

\begin{tabular}{|c|c|c|}
\hline Variable Name & Variable Description & Source \\
\hline \multicolumn{3}{|c|}{ Commuting time equation variables } \\
\hline Commuting time & Weekly hours of commuting from/to work, 1994-1996, 1998 & RLMS9498 \\
\hline Female & 1 if female; 0 if male & RLMS9498 \\
\hline Years of schooling & Highest year of school attended & RLMS9498 \\
\hline Age & Years & RLMS9498 \\
\hline Available public transportation & $\begin{array}{l}1 \text { if city has only buses; } 2 \text { if city has also trams and/or trolley buses; } 3 \text { if city has subway; } \\
1994-1996,1998\end{array}$ & GKSCITY \\
\hline Route length & Average length of a route, km, 1994-1996, 1998 & GKSCITY \\
\hline Number of public vehicles & Number of buses, trams and trolley buses per 1,000 population, 1994-1996, 1998 & GKSCITY \\
\hline Number of passengers & Annual sum of passengers per capita, 1994-1996, 1998 & GKSCITY \\
\hline
\end{tabular}

\section{Sources:}

RLMS2000 $-9^{\text {th }}$ round of the Russian Longitudinal Monitoring Survey, conducted in October-December 2000

RLMS9498 $-5-8^{\text {th }}$ rounds of the Russian Longitudinal Monitoring Survey, conducted in 1994-1996 and 1998

GKS2000 - Goskomstat, Regions of Russia 2000, Moscow: Goskomstat, 2000

GKSCITY - Goskomstat Database, Annual Registries of Russian Cities, 1994-1999

PSD - Practical Science Database

RISK - Matiyasevich T., et al. "Russia: Regional Risk Rating," Vienna: Bank Austria AG, 1998

Regional wage coefficients are provided by the deputy parliament group on social policy 
Table 2: Wage Equation with Amenities, RLMS Cities, 2000

\begin{tabular}{|c|c|c|c|c|c|c|}
\hline OLS with Clustering & Coeff. & $t$ & Mean & $\begin{array}{l}\text { Std. } \\
\text { Dev. }\end{array}$ & Min & $\operatorname{Max}$ \\
\hline \multicolumn{7}{|c|}{ Dependent Variable } \\
\hline Log of monthly wages & & & 7.235 & 0.842 & 3.00 & 11.51 \\
\hline For reference: monthly wages, rubl & & & 1,995 & 2,671 & 20 & 100,000 \\
\hline \multicolumn{7}{|c|}{ Human Capital Characteristics } \\
\hline Log of monthly hours & 0.428 & 10.79 & 5.100 & 0.378 & 1.39 & 6.33 \\
\hline Female & -0.355 & -13.24 & 0.529 & 0.499 & 0 & 1 \\
\hline Married & 0.045 & 1.57 & 0.658 & 0.474 & 0 & 1 \\
\hline Years of schooling & 0.051 & 7.09 & 12.262 & 2.243 & 3 & 18 \\
\hline Actual experience & 0.024 & 5.95 & 20.997 & 12.299 & 0 & 62 \\
\hline Experience squared / 100 & -0.055 & -7.25 & 5.921 & 6.017 & 0 & 38.44 \\
\hline Tenure & 0.011 & 2.63 & 7.259 & 8.855 & 0 & 58.75 \\
\hline Tenure squared / 100 & -0.016 & -1.46 & 1.311 & 2.918 & 0 & 34.52 \\
\hline \multicolumn{7}{|c|}{ Occupations } \\
\hline Officials and managers & 0.443 & 5.84 & 0.046 & 0.210 & 0 & 1 \\
\hline Professionals & 0.449 & 8.31 & 0.167 & 0.373 & 0 & 1 \\
\hline Associate professionals & 0.281 & 5.90 & 0.179 & 0.384 & 0 & 1 \\
\hline Clerks & 0.144 & 3.04 & 0.066 & 0.248 & 0 & 1 \\
\hline Service workers & -0.028 & -0.53 & 0.107 & 0.309 & 0 & 1 \\
\hline Craft workers & 0.250 & 5.54 & 0.181 & 0.385 & 0 & 1 \\
\hline Operators/assemblers & 0.277 & 6.59 & 0.149 & 0.357 & 0 & 1 \\
\hline Military specialists & 0.105 & 1.25 & 0.013 & 0.113 & 0 & 1 \\
\hline Self-employed & 0.141 & 0.06 & 0.086 & 0.281 & 0 & 1 \\
\hline \multicolumn{7}{|c|}{ Amenities/Disamenities } \\
\hline Heating degree days / 100 (cold) & 0.416 & 2.05 & 1.431 & 0.228 & 0.81 & 1.85 \\
\hline Total precipitation / 100 & 0.068 & 1.72 & 5.335 & 1.384 & 3.29 & 8.21 \\
\hline Air pollution & 0.006 & 0.71 & 2.837 & 3.066 & 0.15 & 13.04 \\
\hline Water pollution & 0.016 & 2.83 & 5.924 & 7.014 & 0.00 & 27.36 \\
\hline Home phone lines & -0.865 & -2.62 & 0.194 & 0.089 & 0.07 & 0.71 \\
\hline Doctors & -0.417 & -2.58 & 0.621 & 0.248 & 0.21 & 1.12 \\
\hline Commuting time & 0.274 & 2.16 & 4.519 & 0.430 & 3.70 & 5.38 \\
\hline Crime rate & 0.010 & 2.32 & 21.032 & 7.803 & 8.21 & 42.87 \\
\hline Morbidity rate & 0.806 & 2.42 & 0.736 & 0.102 & 0.52 & 0.94 \\
\hline Capital city & -0.213 & -1.63 & 0.599 & 0.490 & 0 & 1 \\
\hline Ethnic-political risk & 0.046 & 2.89 & 1.700 & 1.692 & 0.17 & 8.92 \\
\hline \multicolumn{7}{|c|}{ Disequilibrium Variables } \\
\hline Share of loss-making firms & -1.817 & -4.17 & 0.336 & 0.089 & 0.12 & 0.57 \\
\hline Employment change & 2.029 & 1.51 & -0.032 & 0.030 & -0.12 & 0.02 \\
\hline Constant & 1.664 & 2.21 & & & & \\
\hline \multicolumn{7}{|c|}{$\begin{array}{l}\text { F-test for eleven amenities/disamenities: } \mathrm{F}(11,38)=9.51 \\
\text { F-test for two disequilibrium variables: } \mathrm{F}(2,38)=12.3\end{array}$} \\
\hline
\end{tabular}

Notes: Dependent variable is log of average monthly wages in rubles. Elementary occupations are omitted from the list of occupation dummies. 15 industry dummies are included but not shown. The t-statistics are defined with robust clustered standard errors allowing for correlation within the 39 RLMS cities. 
Table 3: Housing Value Equation with Amenities, RLMS Cities, 2000

\begin{tabular}{|c|c|c|c|c|c|c|}
\hline Main Regression & Coeff. & $\mathbf{Z}$ & Mean & Std. Dev. & Min & $\operatorname{Max}$ \\
\hline \multicolumn{7}{|c|}{ Dependent Variable } \\
\hline Log of housing market value & & & 12.070 & 0.770 & 8.70 & 14.73 \\
\hline For reference: house values, rubles & & & 234,892 & 223,587 & 6,000 & $2,500,000$ \\
\hline \multicolumn{7}{|c|}{ Housing Characteristics } \\
\hline Living space & 0.028 & 14.22 & 32.822 & 12.842 & 6 & 150 \\
\hline Share of non-living space & 1.225 & 5.17 & 0.356 & 0.112 & 0 & 0.83 \\
\hline Privatized housing & 0.037 & 1.28 & 0.639 & 0.480 & 0 & 1 \\
\hline Central heating & 0.047 & 0.56 & 0.877 & 0.328 & 0 & 1 \\
\hline Central water supply & 0.122 & 2.02 & 0.918 & 0.274 & 0 & 1 \\
\hline Hot water supply & 0.208 & 3.62 & 0.712 & 0.453 & 0 & 1 \\
\hline Piped gas & 0.157 & 2.25 & 0.876 & 0.329 & 0 & 1 \\
\hline Central sewerage & 0.155 & 1.61 & 0.858 & 0.350 & 0 & 1 \\
\hline Home phone & 0.177 & 5.03 & 0.590 & 0.492 & 0 & 1 \\
\hline \multicolumn{7}{|c|}{ Amenities/Disamenities } \\
\hline Heating degree days / 100 (cold) & -0.167 & -0.72 & 1.435 & 0.247 & 0.81 & 1.85 \\
\hline Total precipitation / 100 & 0.005 & 0.11 & 5.121 & 1.328 & 3.29 & 8.21 \\
\hline Air pollution & -0.009 & -0.94 & 2.899 & 3.233 & 0.15 & 13.04 \\
\hline Water pollution & 0.029 & 3.97 & 5.064 & 6.349 & 0.00 & 27.36 \\
\hline Home phone lines & -0.540 & -1.06 & 0.184 & 0.081 & 0.07 & 0.71 \\
\hline Doctors & -0.568 & -3.32 & 0.600 & 0.247 & 0.21 & 1.12 \\
\hline Commuting time & 0.474 & 2.90 & 4.481 & 0.414 & 3.70 & 5.38 \\
\hline Crime rate & 0.006 & 0.81 & 21.265 & 7.678 & 8.21 & 42.87 \\
\hline Morbidity rate & 0.240 & 0.58 & 0.732 & 0.104 & 0.52 & 0.94 \\
\hline Capital city & 0.067 & 0.39 & 0.570 & 0.495 & 0 & 1 \\
\hline Ethnic-political risk & 0.045 & 2.38 & 1.710 & 1.599 & 0.17 & 8.92 \\
\hline \multicolumn{7}{|c|}{ Disequilibrium Variables } \\
\hline Share of loss-making firms & -2.525 & -3.40 & 0.345 & 0.092 & 0.12 & 0.57 \\
\hline Employment change & 3.063 & 2.26 & -0.031 & 0.031 & -0.12 & 0.02 \\
\hline Constant & 8.991 & 10.41 & & & & \\
\hline \multicolumn{7}{|c|}{$\begin{array}{l}\text { F-test for eleven amenities/disamenities: } F(11,38)=19.63 \\
\text { F-test for two disequilibrium variables: } F(2,38)=10.94\end{array}$} \\
\hline
\end{tabular}

Notes: Dependent variable is log of housing market value in rubles. The sample is restricted to households which occupy their own houses and which live in cities. The t-statistics are defined with robust clustered standard errors allowing for correlation within 39 RLMS cities. 
Table 4: Implicit Prices for City Amenities, Alternative Estimation Methods, 2000

\begin{tabular}{|c|c|c|c|c|c|c|}
\hline & $\begin{array}{c}\text { OLS } \\
\text { Benchmark }\end{array}$ & Heckman & FGLS & SUEST & SUREG & $\begin{array}{c}\text { QOLI } \\
\text { Changes } \\
\end{array}$ \\
\hline \multirow[t]{2}{*}{ Heating degree days (cold) } & -0.282 & -0.282 & -0.266 & -0.308 & -0.323 & -7.496 \\
\hline & $(-2.14)$ & $(-2.14)$ & $(-2.41)$ & $(-3.15)$ & $(-4.05)$ & \\
\hline \multirow[t]{2}{*}{ Total precipitation } & -0.042 & -0.042 & -0.041 & -0.039 & -0.045 & -6.695 \\
\hline & $(-1.67)$ & $(-1.65)$ & $(-1.93)$ & $(-1.82)$ & $(-3.33)$ & \\
\hline \multirow[t]{2}{*}{ Air pollution } & -0.446 & -0.460 & -0.334 & 0.014 & 0.068 & -5.355 \\
\hline & $(-0.87)$ & $(-0.90)$ & $(-0.76)$ & $(0.03)$ & $(0.17)$ & \\
\hline \multirow[t]{2}{*}{ Water pollution } & -0.715 & -0.706 & -0.739 & -0.803 & -0.628 & -5.072 \\
\hline & $(-1.96)$ & $(-1.93)$ & $(-2.44)$ & $(-2.59)$ & $(-2.22)$ & \\
\hline \multirow[t]{2}{*}{ Home phone lines } & 49.473 & 50.566 & 51.522 & 42.749 & 65.180 & 4.260 \\
\hline & $(2.29)$ & $(2.34)$ & $(2.90)$ & $(2.36)$ & $(3.50)$ & \\
\hline \multirow[t]{2}{*}{ Doctors } & 20.672 & 20.779 & 16.302 & 15.695 & 11.931 & 3.398 \\
\hline & (1.99) & $(2.00)$ & $(1.64)$ & $(1.58)$ & $(1.33)$ & \\
\hline \multirow[t]{2}{*}{ Commuting time } & -12.548 & -12.304 & -13.795 & -13.429 & -14.079 & -4.213 \\
\hline & $(-1.52)$ & $(-1.49)$ & $(-2.07)$ & $(-2.31)$ & $(-3.48)$ & \\
\hline \multirow[t]{2}{*}{ Crime rate } & -0.595 & -0.600 & -0.645 & -0.449 & -0.505 & -9.371 \\
\hline & $(-2.05)$ & $(-2.07)$ & $(-2.69)$ & $(-1.75)$ & $(-2.60)$ & \\
\hline \multirow[t]{2}{*}{ Morbidity rate } & -48.779 & -48.248 & -49.155 & -51.810 & -41.436 & -5.614 \\
\hline & $(-2.26)$ & $(-2.23)$ & $(-2.75)$ & $(-2.91)$ & $(-3.10)$ & \\
\hline \multirow[t]{2}{*}{ Capital city } & 14.206 & 13.982 & 17.001 & 18.969 & 18.986 & 3.600 \\
\hline & $(1.68)$ & $(1.65)$ & $(2.42)$ & $(2.77)$ & $(3.61)$ & \\
\hline \multirow[t]{2}{*}{ Ethnic-political risk } & -2.460 & -2.439 & -2.145 & -2.294 & -3.257 & -4.984 \\
\hline & $(-2.40)$ & $(-2.38)$ & $(-2.78)$ & $(-2.56)$ & $(-3.80)$ & \\
\hline $\mathrm{N}-$ wage equation & 3017 & 3017 & 3017 & 1796 & 1087 & \\
\hline $\mathrm{N}-$ housing equation & 1489 & $1487 / 2331$ & 1489 & 1489 & 1087 & \\
\hline $\mathrm{R}^{2}$ - wage equation & 0.464 & 0.464 & 0.499 & 0.473 & 0.495 & \\
\hline $\mathrm{R}^{2}$ - housing equation & 0.603 & $\ldots$ & 0.604 & 0.603 & 0.584 & \\
\hline \multirow{3}{*}{ Samples } & Separate & Separate & Separate & Matched & Matched & \\
\hline & workers & workers & workers & HH heads & HH heads & \\
\hline & $\&$ houses & $\&$ houses & $\&$ houses & $\&$ houses & $\&$ houses & \\
\hline
\end{tabular}

Notes: QOLI changes show changes in the mean value of quality of life index in response to one standard deviation increase in the amount of corresponding amenity using OLS estimates. Robust standard errors adjusted for clustering in 39 RLMS cities are in parentheses, except for SUREG. Full implicit prices are estimated at the mean of housing values and wages. The number of workers per household is measured in full-time equivalent units as a ratio of total working hours of all household members to the average hours in the sample. Average number of full-time workers per household is 2.65. Interest rate is $4.35 \%$. Mean wages is 1995 rubles per month. Mean housing value is 234,892 rubles. FGLS=feasible generalized least squares; SUEST=seemingly unrelated estimation; SUREG=seemingly unrelated regression; $\mathrm{HH}=$ household. Breusch-Pagan test of independence in SUREG: $\operatorname{chi}^{2}(1)=16.149(\mathrm{P}=0.0001)$. 
Table 5: Implicit Prices for City Amenities, Alternative Specifications, 2000

\begin{tabular}{|c|c|c|c|c|c|c|}
\hline \multirow{2}{*}{$\begin{array}{c}\text { Amenities and Disequilibrium } \\
\text { Variables }\end{array}$} & \multicolumn{2}{|c|}{$\begin{array}{c}\text { Wage Differential } \\
\text { (OLS) }\end{array}$} & \multicolumn{2}{|c|}{$\begin{array}{c}\text { Housing Value } \\
\text { Differential (OLS) }\end{array}$} & \multicolumn{2}{|c|}{ Full Implicit Price } \\
\hline & Coeff. & $t$ & Coeff. & $t$ & Coeff. & $T$ \\
\hline \multicolumn{7}{|c|}{ A. Specification with government regional wage coefficients } \\
\hline Heating degree days / 100 (cold) & 0.020 & 0.11 & -0.506 & -1.76 & -6.429 & -0.53 \\
\hline Total precipitation / 100 & 0.053 & 1.69 & -0.008 & -0.18 & -3.430 & -1.69 \\
\hline Air pollution & 0.001 & 0.21 & -0.010 & -1.04 & -0.184 & -0.45 \\
\hline Water pollution & 0.008 & 1.91 & 0.022 & 2.80 & -0.286 & -1.02 \\
\hline Home phone lines & -0.208 & -0.56 & 0.038 & 0.07 & 13.584 & 0.56 \\
\hline Doctors & -0.316 & -2.07 & -0.492 & -2.83 & 15.049 & 1.53 \\
\hline Commuting time & 0.273 & 1.90 & 0.471 & 2.69 & -12.523 & -1.35 \\
\hline Crime rate & 0.002 & 0.35 & 0.000 & 0.04 & -0.109 & -0.34 \\
\hline Morbidity rate & 0.464 & 1.51 & 0.026 & 0.06 & -29.237 & -1.46 \\
\hline Capital city & -0.203 & -1.32 & 0.093 & 0.52 & 13.866 & 1.39 \\
\hline Ethnic-political risk & 0.024 & 2.38 & 0.025 & 1.30 & -1.278 & -1.90 \\
\hline Share of loss-making firms & -1.709 & -5.18 & -2.405 & -3.98 & $\ldots$ & $\ldots$ \\
\hline Employment change & 1.459 & 1.39 & 2.444 & 2.00 & $\cdots$ & $\cdots$ \\
\hline Gov't. regional wage coefficients & 0.585 & 3.95 & 0.463 & 2.15 & $\ldots$ & $\ldots$ \\
\hline Test for 11 amenities/disamenities & \multicolumn{2}{|c|}{$\mathrm{F}(11,38)=8.66$} & \multicolumn{2}{|c|}{$\mathrm{F}(11,38)=11.37$} & & \\
\hline Test for 2 disequilibrium variables & \multicolumn{2}{|c|}{$F(2,38)=15.17$} & \multicolumn{2}{|c|}{$\mathrm{F}(2,38)=14.27$} & & \\
\hline Test for 2 climate variables & \multicolumn{2}{|c|}{$\mathrm{F}(2,38)=1.53$} & \multicolumn{2}{|c|}{$\mathrm{F}(2,38)=1.67$} & & \\
\hline & \multicolumn{2}{|c|}{$\mathrm{N}=3017$} & \multicolumn{2}{|c|}{$\mathrm{N}=1489$} & & \\
\hline & \multicolumn{2}{|c|}{$\mathrm{R}^{2}=0.477$} & \multicolumn{2}{|c|}{$\mathrm{R}^{2}=0.612$} & & \\
\hline \multicolumn{7}{|c|}{ B. Specification with alternative amenity variables } \\
\hline Temperature in warm period / 100 & -0.018 & -1.59 & 0.013 & 1.39 & 1.302 & 1.75 \\
\hline Precipitation in cold period / 100 & 0.206 & 2.07 & 0.100 & 0.96 & -12.089 & -1.88 \\
\hline Sulfur fall-out & 0.053 & 0.87 & 0.009 & 0.17 & -3.282 & -0.84 \\
\hline Water pollution & 0.019 & 4.39 & 0.031 & 6.56 & -0.863 & -3.15 \\
\hline Total phone lines & -0.929 & -3.43 & -0.453 & -1.01 & 54.396 & 3.06 \\
\hline Doctors & -0.256 & -1.99 & -0.540 & -3.32 & 10.736 & 1.29 \\
\hline Commuting time & 0.285 & 2.09 & 0.456 & 2.60 & -13.468 & -1.52 \\
\hline Crime rate & 0.012 & 2.16 & 0.009 & 1.29 & -0.690 & -1.86 \\
\hline Morbidity rate & 0.810 & 2.23 & 0.405 & 0.89 & -47.353 & -2.01 \\
\hline Capital city & -0.242 & -1.65 & 0.068 & 0.40 & 16.076 & 1.70 \\
\hline Ethnic-political risk & 0.028 & 2.43 & 0.051 & 3.43 & -1.274 & -1.69 \\
\hline Share of loss-making firms & -1.808 & -3.59 & -2.438 & -3.69 & $\ldots$ & $\ldots$ \\
\hline \multirow[t]{2}{*}{ Employment change } & 3.020 & 1.78 & 3.767 & 2.63 & $\ldots$ & $\ldots$ \\
\hline & \multicolumn{2}{|c|}{$\mathrm{N}=3017$} & \multicolumn{2}{|c|}{$\mathrm{N}=1489$} & & \\
\hline
\end{tabular}

Notes: t-statistics are defined with robust clustered standard errors allowing for correlation within 39 cities. Summary statistics for alternative amenity variables is provided in Appendix 1. Both specifications also include the same set of human capital and housing characteristics as Tables 2 and 3. Full implicit prices are estimated at the mean of housing values and wages. Sample is restricted to respondents residing in cities. 


\begin{tabular}{|c|c|c|}
\hline & $\begin{array}{c}\text { Correlation } \\
\text { between QOLI } \\
\text { Values }\end{array}$ & $\begin{array}{c}\text { Spearman's } \\
\text { Correlation } \\
\text { between } \\
\text { Rankings } \\
\end{array}$ \\
\hline \multicolumn{3}{|l|}{ Alternative QOLI Rankings: } \\
\hline $\begin{array}{l}\text { 1. With government regional wage coefficients (all } 953 \\
\text { cities) }\end{array}$ & 0.8604 & 0.8239 \\
\hline $\begin{array}{l}\text { 2. With government regional wage coefficients (39 RLMS } \\
\text { cities) }\end{array}$ & 0.8230 & 0.7925 \\
\hline $\begin{array}{l}\text { 3. With Moscow and St. Petersburg included as a dummy } \\
\text { variable (all } 953 \text { cities) }\end{array}$ & 0.9801 & 0.9854 \\
\hline $\begin{array}{l}\text { 4. With alternative amenity variables described in Table } 5 \text { (all } \\
953 \text { cities) }\end{array}$ & 0.9011 & 0.9000 \\
\hline $\begin{array}{l}\text { 5. With the level of subsistence (all } 953 \text { cities) } \\
\text { (Mean=0.148; Std.Dev. }=0.043 \text { ) }\end{array}$ & 0.9803 & 0.9792 \\
\hline 6. With survey weights (all 953 cities) & 0.9964 & 0.9941 \\
\hline $\begin{array}{l}\text { 7. With wages actually received last month in the OLS wage } \\
\text { equation (all } 953 \text { cities) }\end{array}$ & 0.9643 & 0.9605 \\
\hline $\begin{array}{l}\text { 8. Based on the Heckman ML housing equation (with sample } \\
\text { selection, all } 953 \text { cities) }\end{array}$ & 0.9999 & 0.9999 \\
\hline 9. Using feasible generalized least squares (all 953 cities) & 0.9951 & 0.9966 \\
\hline 10. Based on seemingly unrelated regressions (all 953 cities) & 0.9148 & 0.9634 \\
\hline $\begin{array}{l}\text { 11. With city fixed effects ( } 39 \text { RLMS cities, amenities plus } \\
\text { disequilibrium variables) }\end{array}$ & 0.4674 & 0.6055 \\
\hline \multicolumn{3}{|l|}{ Government Regional Wage Coefficients } \\
\hline 1. All 953 cities & -0.3869 & -0.4893 \\
\hline 2. 39 RLMS cities & -0.6602 & -0.5967 \\
\hline \multicolumn{3}{|l|}{ Mobility Change } \\
\hline $\begin{array}{l}\text { 1. Average mobility change in 1994-1999 (all } 953 \text { cities) } \\
\text { (Mean=3.112; Std.Dev. }=8.767 \text { ) }\end{array}$ & 0.2699 & 0.2134 \\
\hline $\begin{array}{l}\text { 2. Average mobility change in } 1998-1999 \text { (all } 953 \text { cities) } \\
(\text { Mean=0.678; Std.Dev. }=9.234)\end{array}$ & 0.2452 & 0.1788 \\
\hline
\end{tabular}

Notes: The table shows the coefficients of correlation between the base QOLI values and alternative QOLI values. The table also contains the coefficients of correlation between the base QOLI values and government regional wage "coefficients" and between the base QOLI values and the change in city mobility. Average mobility change is defined as an average annual change in population due to migration per 1,000 city residents. Mean value and standard deviation for average mobility change and the level of subsistence are shown in parentheses. 
Appendix 1: Sample Mean Comparison Tests

\begin{tabular}{|c|c|c|c|c|c|c|}
\hline \multirow[t]{2}{*}{ Variables } & \multicolumn{2}{|c|}{$\begin{array}{l}\text { Sample of } \\
\text { 953 Cities }\end{array}$} & \multicolumn{2}{|c|}{$\begin{array}{l}\text { Sample of } \\
39 \text { RLMS Cities }\end{array}$} & \multirow{2}{*}{$\begin{array}{c}\text { Two- } \\
\text { Sample } \\
\text { t Test }\end{array}$} & \multirow[t]{2}{*}{ P-value } \\
\hline & Mean & Std.Dev. & Mean & Std.Dev. & & \\
\hline Heating degree days /100 (cold) & 1.428 & 0.266 & 1.415 & 0.212 & 0.363 & 0.719 \\
\hline Temperature in warm period /100 & 20.387 & 6.024 & 20.626 & 4.792 & -0.302 & 0.764 \\
\hline Total precipitation /100 & 5.428 & 1.524 & 5.596 & 1.449 & -0.711 & 0.481 \\
\hline Precipitation in cold period $/ 100$ & 1.422 & 0.559 & 1.425 & 0.435 & -0.044 & 0.965 \\
\hline Air pollution & 2.696 & 12.733 & 2.170 & 2.650 & 0.889 & 0.376 \\
\hline Sulfur fall-out & 1.056 & 10.761 & 0.483 & 0.785 & 1.545 & 0.123 \\
\hline Water pollution & 2.802 & 7.232 & 5.136 & 6.483 & -2.193 & 0.034 \\
\hline Total phone lines & 0.202 & 0.092 & 0.246 & 0.128 & -2.125 & 0.040 \\
\hline Home phone lines & 0.162 & 0.076 & 0.199 & 0.106 & -2.161 & 0.037 \\
\hline Doctors & 0.392 & 0.169 & 0.552 & 0.249 & -3.971 & 0.000 \\
\hline Commuting time & 4.094 & 0.354 & 4.356 & 0.440 & -3.667 & 0.001 \\
\hline Crime rate & 23.901 & 15.428 & 20.140 & 8.793 & 2.517 & 0.015 \\
\hline Morbidity rate & 0.698 & 0.119 & 0.711 & 0.107 & -0.749 & 0.458 \\
\hline Capital city & 0.079 & 0.269 & 0.385 & 0.493 & -3.853 & 0.000 \\
\hline Ethnic-political risk & 1.650 & 2.158 & 1.514 & 1.497 & 0.543 & 0.590 \\
\hline Government regional wage coeffs. & 1.207 & 0.012 & 1.158 & 0.043 & 1.112 & 0.272 \\
\hline
\end{tabular}

Note: The t-statistics show the results of two-sample $t$ test with unequal variances on the equality of means.

Appendix 2: Commuting Time Equation, RLMS Cities, 1994-1996, 1998

\begin{tabular}{lcc|cccc}
\hline \multicolumn{1}{c}{ OLS } & Coeff. & $\boldsymbol{t}$ & Mean & Std. Dev. & Min & Max \\
\hline Dependent variable - Hours of commuting time per week & & & & & & \\
Female & -0.792 & -9.44 & 0.508 & 0.500 & 0 & 1 \\
Age & -0.005 & -1.29 & 39.455 & 12.100 & 14 & 82 \\
Years of schooling & 0.065 & 3.83 & 12.015 & 2.587 & 0 & 18 \\
Available public transportation & & & & & & \\
Only buses (omitted) & & & 0.361 & 0.480 & 0 & 1 \\
Trams and trolley buses & 0.729 & 5.87 & 0.458 & 0.498 & 0 & 1 \\
Subway & 1.128 & 5.96 & 0.181 & 0.385 & 0 & 1 \\
Route length & 0.032 & 1.99 & 10.193 & 2.603 & 4.58 & 23.60 \\
Number of passengers / 100 & 0.043 & 1.69 & 4.525 & 2.892 & 0.04 & 11.26 \\
Number of public vehicles & -0.417 & -2.55 & 0.920 & 0.355 & 0.08 & 1.68 \\
Constant & 3.856 & 11.72 & & & & \\
\hline
\end{tabular}

Notes: Year dummies are included for three of the four years. The t-statistics are defined with robust standard errors. The sample is limited to the 39 cities included in the RLMS for the years in which the commuting question was asked. 
Appendix 3: Housing Value Equation with City Amenities, 2000

(Heckman ML Model with Sample Selection and Clustering)

\begin{tabular}{|c|c|c|c|c|}
\hline & \multicolumn{2}{|c|}{ Main Regression } & \multicolumn{2}{|c|}{ Selection Equation } \\
\hline & Coeff. & $\mathbf{Z}$ & Coeff. & $\mathbf{z}$ \\
\hline \multicolumn{5}{|c|}{ Characteristics of the Reference Person in a Household } \\
\hline Female & $\ldots$ & $\ldots$ & 0.095 & 1.15 \\
\hline Age & $\ldots$ & $\ldots$ & -0.014 & -6.04 \\
\hline Years of schooling & $\ldots$ & $\ldots$ & 0.041 & 4.35 \\
\hline Computer skills & $\ldots$ & $\ldots$ & 0.341 & 3.55 \\
\hline \multicolumn{5}{|c|}{ Housing Characteristics } \\
\hline Living space & 0.027 & 14.28 & 0.005 & 1.65 \\
\hline Share of non-living space & 1.171 & 5.50 & 0.665 & 2.77 \\
\hline Privatized housing & 0.024 & 0.76 & 0.212 & 3.07 \\
\hline Central heating & 0.059 & 0.71 & -0.082 & -0.49 \\
\hline Central water supply & 0.101 & 1.73 & 0.304 & 2.16 \\
\hline Hot water supply & 0.208 & 3.66 & -0.033 & -0.27 \\
\hline Piped gas & 0.155 & 2.33 & -0.027 & -0.25 \\
\hline Central sewerage & 0.146 & 1.52 & -0.078 & -0.45 \\
\hline Home phone & 0.176 & 4.97 & -0.004 & -0.05 \\
\hline \multicolumn{5}{|c|}{ Amenities/Disamenities } \\
\hline Heating degree days / 100 (cold) & -0.002 & -0.73 & 0.002 & 0.39 \\
\hline Total precipitation / 100 & 0.000 & 0.24 & -0.001 & -1.41 \\
\hline Air pollution & -0.010 & -1.11 & 0.019 & 0.94 \\
\hline Water pollution & 0.030 & 4.15 & -0.012 & -0.97 \\
\hline Home phone lines & -0.433 & -0.88 & -1.134 & -1.73 \\
\hline Doctors & -0.558 & -3.35 & -0.287 & -0.72 \\
\hline Commuting time & 0.497 & 2.86 & -0.332 & -1.56 \\
\hline Crime rate & 0.005 & 0.76 & 0.002 & 0.21 \\
\hline Morbidity rate & 0.291 & 0.69 & -1.137 & -2.21 \\
\hline Capital city & 0.045 & 0.26 & 0.322 & 1.05 \\
\hline Ethnic-political risk & 0.047 & 2.56 & -0.017 & -0.39 \\
\hline \multicolumn{5}{|c|}{ Disequilibrium Variables } \\
\hline Share of loss-making firms & -2.561 & -3.55 & 0.498 & 0.73 \\
\hline Employment change & 2.632 & 2.09 & 5.673 & 1.91 \\
\hline Constant & 8.949 & 9.98 & 2.768 & 2.08 \\
\hline$\lambda$ & & & -0.145 & -1.19 \\
\hline
\end{tabular}

Notes: Dependent variable is log of housing market value, rubles; sample size is restricted to households-occupants of own houses living in cities; $t$-statistics are defined with robust clustered standard errors allowing for correlation within 39 cities. 
Figure 1: Government Regional Wage Coefficients, 2000

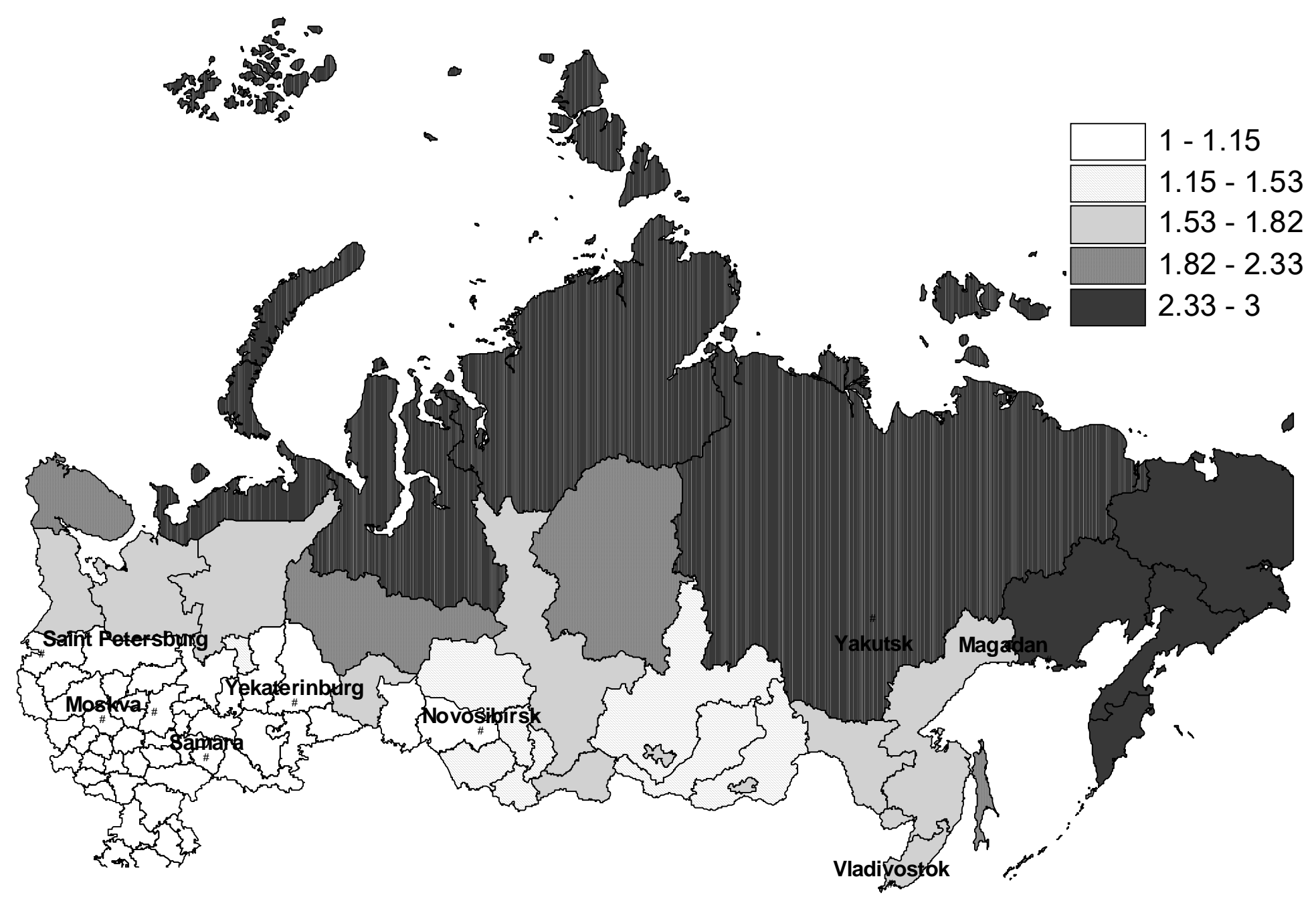


Figure 2: Average City Wages and Housing Prices in 39 RLMS Cities, 2000

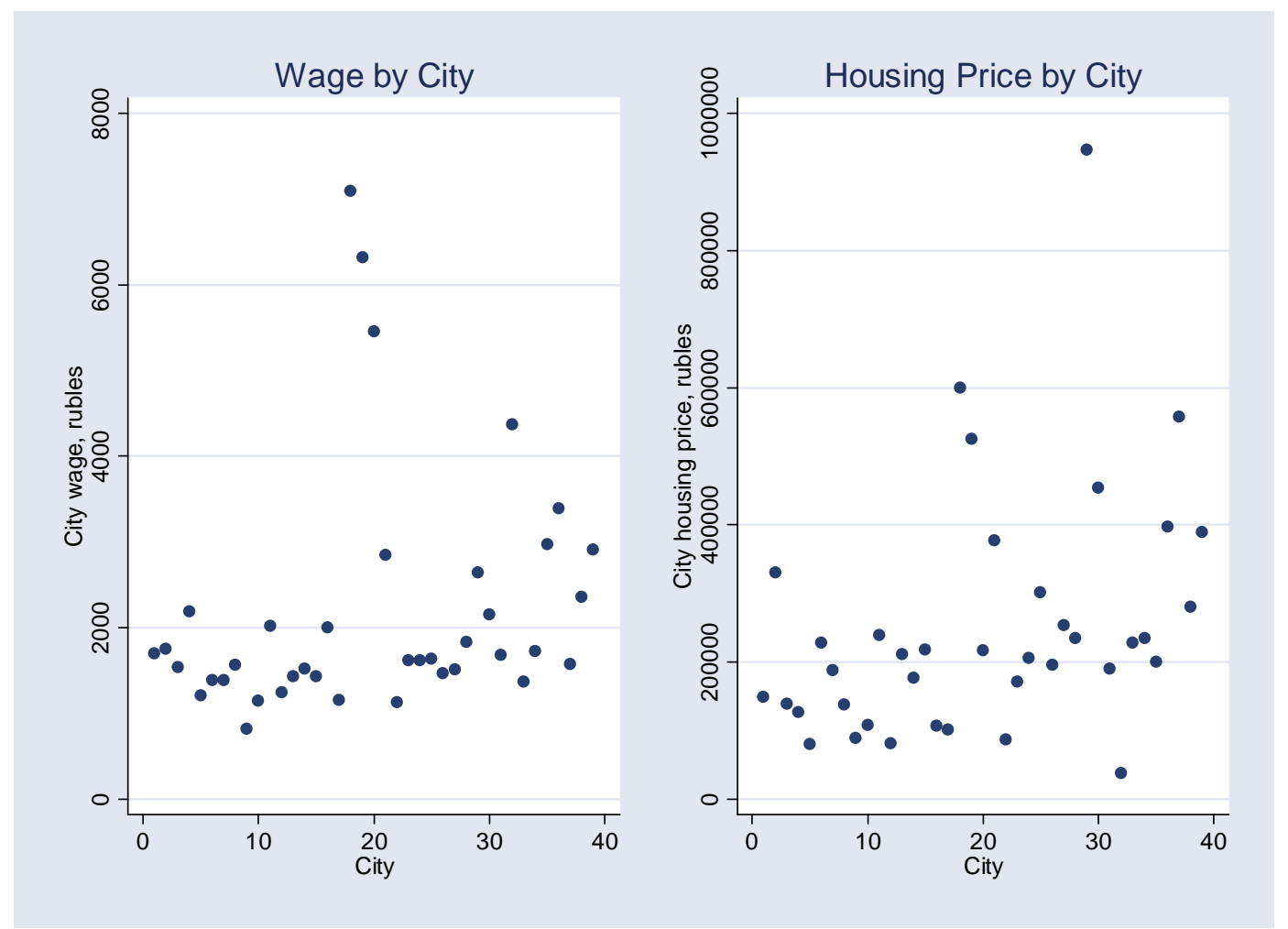

Notes: The outlier in housing prices is Moscow. Three outliers in wages are northern cities in oil-producing fields. Names of all of the cities cannot be disclosed due to confidentiality. 
Figure 3: Quality of Life Index Values by Region in the Russian Federation, 2000

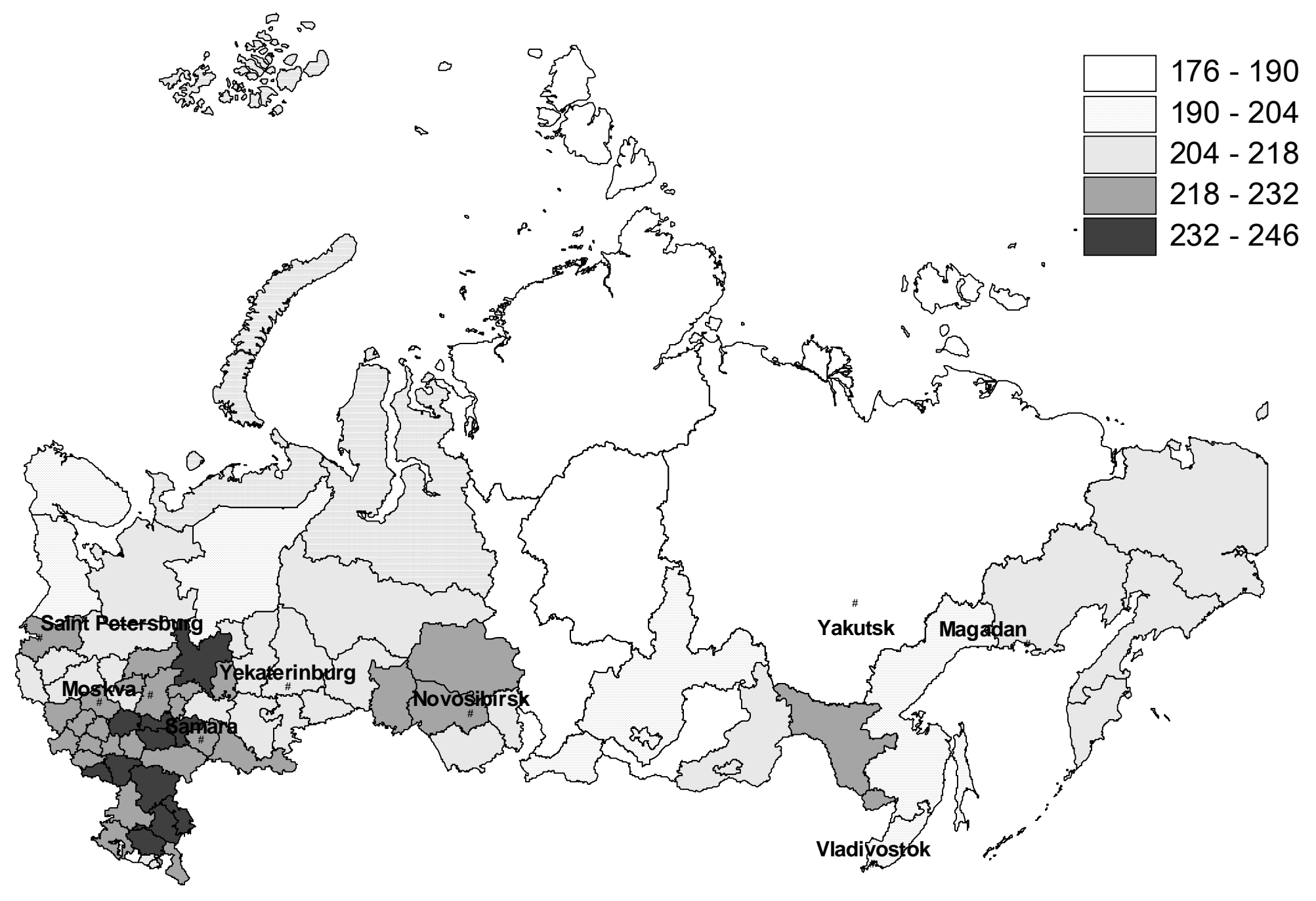

